\title{
Agro-Morphological, Yield Components and Nutritional Quality Attributes of Vicia faba L. var. Minor Cropped in Tunisian Arid Regions
}

\author{
Jamila Yehmed ${ }^{1,2}$, Samir Tlahig',4*, Naziha Ayeb ${ }^{3,5}$, Amina Mohamed ${ }^{1}$, Hédi Yahia ${ }^{1}$, \\ Mohamed Dbara ${ }^{3}$, Mohamed Loumerem ${ }^{1}$ \\ ${ }^{1}$ Dry land Farming and Oases Cropping Laboratory, Arid Lands Institute of Medenine, University of Gabès, Tunisia \\ ${ }^{2}$ Faculty of Sciences of Gabès, University of Gabès, Tunisia \\ ${ }^{3}$ Livestock and Wildlife Laboratory, Arid Lands Institute of Médenine, University of Gabès, Tunisia \\ ${ }^{4}$ Department of Environmental Sciences, Higher Institute of Applied Biology of Medenine (ISBAM), \\ University of Gabes, Tunisia \\ ${ }^{5}$ Regional Center for Agricultural Research (CRRA) Sidi Bouzid, Tunisia
}

Received: 1 April 2021

Accepted: 23 June 2021

\begin{abstract}
Faba bean (Vicia Faba var. Minor) is of great importance as it is commonly used as an excellent protein source in food and feed. In Tunisia, the wide variability among local genetic resources might be valorized by preservation and breeding programs. For that, the knowledge of the diversity within this crop and its distribution across the oasis could be of great help in managing and improving its germplasm. The objectives of the present study were to assess the phenotypic diversity within a germplasm of 23 populations of local faba bean cropped in Tunisian arid regions. Characterization was undertaken based on 29 parameters related to seeds, plant growth, flowers, and pods characteristic. This agro-morphological characterization was carried out based on UPOV and Bioversity International descriptors. Crude protein (CP), neutral and acid detergent fibers (NDF, ADF), and in vitro dry/organic matter digestibility (IVDMD/IVOMD) parameters were also analyzed. Results revealed a considerable genetic variability for most of the agro-morphological parameters. In fact, significant differences $(p<0.05)$ were revealed by ANOVA for the majority of the analyzed quantitative traits. The coefficient of variation, used as a homogeneity index, was above $1.44 \%$ for all characters, which ensures the predominance of genetic components in the differences among populations. The overall variability was analyzed via multivariate and dimension reduction approaches relatively using hierarchical clustering and PCA methods, in order to classify populations into relatively homogenous groups after the identification of the major traits contributing to the overall diversity. The superior populations with the best precocity (95 DAS), with high total yielding per plant $(500 \mathrm{~g})$, and having the highest digestibility (96.5\%), the highest CP content (29.6\%), and the least NDF content (44.5\%) were identified.
\end{abstract}

*e-mail: samirtlahig@gmail.com 
This assessment of traits diversity can assist breeders to manage and to valorize populations with desirable characteristics to be used in various breeding programs.

Keywords: germplasm, feed, breeding, multivariate analysis, Vicia faba var. minor

\section{Introduction}

Faba bean (Vicia faba L. var. minor) is the most important grain legume for direct human consumption. In recent years, cultivation of this crop has received large attention in Canada, USA and Europe [1-3]. As a legume, faba bean has the ability to fix atmospheric nitrogen via symbioses with rhizobia bacteria. Thus, improving soil quality and saving nitrogen fertilizer [4-6].

In addition to being high in protein $19-39 \%$ dry weight $[7,8]$ with a high level of lysine, Faba bean flour had a high content of starch (27-50\% dry weight) [9]. Furthermore, the beans, whose outer seed coat is removed, can be eaten raw or cooked in several regions such as North Africa, West Asia, and Ethiopia. Moreover, faba bean has a valuable potential as animal feed, particularly as an alternative to soybean (Glycine $\max (\mathrm{L}$.$) Merr.) [10,11]$.

Nevertheless, the majority of seed legume crops are facing a lack of performance due to low yields and yield instability over seasons and environments; inducing insufficiency and unprofitability for farmers [12, 13].

In Tunisia, this problem increases with aridity and the sustainable use of saline water in irrigated agriculture of the southern region environment. Native faba bean germplasm is imperatively being more valorized for an efficient use in feed production. Several studies have been carried out on faba bean and other legume species [14], considering mainly genetic [15], physiological [16] Phyto-pathological [17] and biochemical [18] assessments.

Actually, according to the last statistics provided by the Tunisian ministry of agriculture, faba bean is cropped on 52100 ha where the production reaches about 67500 tons [19].

To cope with the rising cost of raw materials used for the animal feed industry (soybean and maize), researchers in Tunisia are increasingly interested in developing performing local fodder protein sources such as faba bean [20-22].

These genetic resources exhibit a wide diversity that would be useful to perform breeding programs promising genotypes providing high performance (yield, feed quality, etc.), and ensuring an acceptable genetic fitness and stability under varying environmental conditions [23].

In this context, a breeding program which concerns a collection of faba bean genetic resources collected from different Tunisian oases in order to preserve this germplasm and develop new high-performance synthetic varieties. This breeding program had been undertaken in the Arid Lands Institute aiming to create new varieties adapted to a changing climate of arid regions [24]. The present study was performed as a part of this program. Twenty-three faba bean genotypes were evaluated for their agro-morphological performance, chemical composition, and in vitro digestibility. The high-performing plants and the most interesting traits will be used for selection and breeding program.

\section{Experimental}

\section{Plant Material and Experimental Design}

Twenty-three faba bean (Vicia faba L. var. minor) populations were originally collected and assembled

Table 1. Climatic data during trial period (from October 2015 to May 2016) along the experimental period under open field conditions.

\begin{tabular}{|c|c|c|c|c|c|c|c|}
\hline Months & $\mathrm{T}\left({ }^{\circ} \mathrm{C}\right)$ & $\mathrm{TM}\left({ }^{\circ} \mathrm{C}\right)$ & $\mathrm{Tm}\left({ }^{\circ} \mathrm{C}\right)$ & $\mathrm{H}(\%)$ & $\mathrm{PP}(\mathrm{mm})$ & $\mathrm{V}(\mathrm{km} / \mathrm{h})$ & $\mathrm{VM}(\mathrm{km} / \mathrm{h})$ \\
\hline October & 24.70 & 30.20 & 20.30 & 58.10 & 59.18 & 8.10 & 14.70 \\
\hline November & 17.20 & 21.50 & 13.30 & 69.70 & 54.11 & 7.60 & 13.70 \\
\hline December & 13.30 & 19.20 & 8.40 & 65.20 & 0.51 & 4.00 & 9.70 \\
\hline January & 14.50 & 19.70 & 9.30 & 49.30 & 1.27 & 7.60 & 16.50 \\
\hline February & 15.80 & 21.10 & 10.00 & 44.50 & 1.02 & 10.60 & 16.70 \\
\hline March & 17.40 & 23.70 & 10.60 & 37.70 & 0.25 & 11.40 & 17.90 \\
\hline April & 20.60 & 27.30 & 14.90 & 51.00 & 1.52 & 11.50 & 18.50 \\
\hline May & 23.60 & 30.20 & 17.80 & 45.60 & 1.78 & 12.50 & 20.40 \\
\hline
\end{tabular}

$\mathrm{T}$ : Average Temperature $\left({ }^{\circ} \mathrm{C}\right), \mathrm{TM}:$ Maximum Temperature $\left({ }^{\circ} \mathrm{C}\right), \mathrm{Tm}:$ Minimum Temperature $\left({ }^{\circ} \mathrm{C}\right), \mathrm{H}:$ Average relative humidity $(\%)$, PP : Total rainfall and/or snowmelt $(\mathrm{m}), \mathrm{V}$ : Average wind $\operatorname{speed}(\mathrm{km} / \mathrm{h}), \mathrm{VM}:$ Maximum sustained wind $\operatorname{speed}(\mathrm{km} / \mathrm{h})$ 
by Arid Lands Institute researcher from the southern Tunisia's oasis.

These populations were grown in the experimental field of the Arid Lands Institute of Medenine located in southern Tunisia $\left(33^{\circ} 29^{\prime} 57.80^{\prime \prime} \mathrm{N}, 1^{\circ} 38^{\prime} 32.96{ }^{\prime} \mathrm{E}\right.$, Altitude $16 \mathrm{~m}$ ). The trial was conducted in a randomized complete block design (RCBD) with three replications. Seeds of faba bean genotypes were planted on $12^{\text {th }}$ of October 2015. Monthly climate data were recorded during the trial period (Table 1). Seeds of faba bean populations were planted in rows with $60 \times 60 \mathrm{~cm}$ of inter-plants distance. Each of the 23 populations was represented by ten plants per row on each block. Soil of experimental research station is loamy sand with low organic matter.

The plots were immediately irrigated after sowing and then subsequently irrigated twice weekly with equal quantities during the trial period and supplied with a mineral fertilizer (NPK 20-20-20). Weeds were hand-controlled, while chemical pesticides are often used to control diseases and pests.

\section{Agro-Morphological Characterization}

These populations were characterized according to the descriptors established by the International Union for the Protection of New Varieties of Plants [25]. A total of 29 agro morphological traits (Table 2) were used. Time of flowering and pod maturity (days) were recorded from visual observations on each planted row (population). At maturity, 10 randomly selected plants from each population (10 samples per population for each block) were used to measure agro-morphological traits on individual plant basis (i.e., plant height was measured from soil surface to the upper most tip of the plant, number of pods bearing branches/plant, number of pods/plants, number of seeds/plant and seed yield/plant). Seed compounds traits were assessed based on 10 randomly sampled pods per plant.

\section{Chemical Composition and in vitro Digestibility}

\section{Chemical Composition}

Three representative samples of seeds per population were subjected to chemical composition surveys. Each sample, composed by $200 \mathrm{~g}$ of seeds, was divided into two parts for independent analysis. The first subsample was dried at $105^{\circ} \mathrm{C}$ to determine the dry matter (DM) content. The second was dried at $65^{\circ} \mathrm{C}$ for $48 \mathrm{~h}$ to determine the chemical composition. Ash was determined by incinerating samples in a furnace at $550^{\circ} \mathrm{C}$ for $6 \mathrm{~h}$ and the crude protein (CP) was determined by Kjeldahl method [26]. Analysis of neutral and acid detergent fibers (NDF, ADF) was performed according to the method described by [27].

\section{In vitro Digestibility}

The in vitro digestibility was estimated using the first step of [28]; this method involves incubating the feed sample for 48 hours in the presence of microbial rumen flora in conditions similar to those of the animal's natural rumen. The incubation was conducted in $100 \mathrm{~mL}$ flasks, adding in each $0.5 \mathrm{~g}$ of each faba sample (ground to $1 \mathrm{~mm}$ ) $40 \mathrm{~mL}$ of artificial saliva (mix of 6 solutions) (Table S1) and $10 \mathrm{~mL}$ of rumen fluid collected by oral esophageal rumen recovery by using a soft and flexible rubber and a vacuum pump (Alcatel, Annecy, France) from three adult goats. Flasks were then transferred to a water bath oven at $39^{\circ} \mathrm{C}$. Simultaneously, a series of blank flasks (without rumen fluid) were prepared. All samples were incubated for $48 \mathrm{~h}$ then saturated with $\mathrm{CO}_{2}$; the $\mathrm{pH}$ was adjusted to 6.8. After incubation, samples were filtered; the residue obtained was dried at $105^{\circ} \mathrm{C}$, then incinerated at $550^{\circ} \mathrm{C}$ and weighted.

In vitro digestibility was calculated as follows:

$$
\begin{aligned}
& \operatorname{IVDMD}(\%)=\frac{I-F 1}{I} \times 100 \\
& \operatorname{IVOMD}(\%)=\frac{I-F 2}{I} \times 100
\end{aligned}
$$

IVDMD : in vitro dry matter digestibility; IVOMD : in vitro organic matter digestibility; $I$ : sample \% DM: the intake; $F 1$ : residual dry weight $\left(105^{\circ} \mathrm{C}\right)$; and $F 2$ : residual ash weight $\left(550^{\circ} \mathrm{C}\right)$.

\section{Statistical Analysis}

Statistical analyzes were performed using One-way ANOVA $(\alpha=0.05)$ on the centered and standardized values for each assessed trait, then population means' comparisons were given by Duncan multi-range test $(p<0.05)$. The structure of genetic variability among populations based on agro-morphological, yield compound, and nutritional quality traits was analyzed using hierarchical cluster analysis (HCA) and Principal Component Analysis (PCA) on the basis of Pearson bi-variate correlations.

\section{Ethics Statement}

Rumen fluid extracts from goats were used in the section of in vitro digestibility experiment. Extractions were approved by the veterinary unit of the Arid Lands Institute (IRA) of Médenine on behalf of the Tunisian committee of ethics in animal experimentation. They were collected, from goats bred in the Wildlife and Livestock Laboratory- IRA, according to protocols approved in the relevant Animal Ethics approvals by sampling through a fistula or via stomach tubing. 
Table 2. Agro-morphological traits of the studied Vicia faba var minor populations.

\begin{tabular}{|c|c|c|}
\hline Code & Trait & Method/Unit \\
\hline \multicolumn{3}{|r|}{ Pheno-morphological traits } \\
\hline STEMCOLOR & Stem color & 3: low; 5: medium; 7 : high \\
\hline GROWHABIT & Growth habit & 1: undetermined; 2 : determined \\
\hline PLANTHGT & Plant height & $\mathrm{cm}$ \\
\hline STEMNBR & Stem number & Count \\
\hline NODNBR & Nodes number by pod & Count \\
\hline LENGTHLEALET & Leaflet length & $\mathrm{cm}$ \\
\hline LEAFLETSHP & Leaflet shape & $\begin{array}{c}\text { Leaflet shape observed on middle leaflet of fully expanded leaf at the interme- } \\
\text { diate flowering node of the plant. } \\
\text { 1: narrow; } 2 \text { : intermediate; } 3 \text { : round }\end{array}$ \\
\hline LEAFCOL & Color of leaflet & 1: light green; 2 : medium green; 3 : dark green \\
\hline FLWPERINF & Flowers per inflorescence & Count \\
\hline MELCOL & Melanin color & 1: brown; 2: black; 3: yellow \\
\hline PIGANTHO & Anthocyanin pigmentation & 1: absent, 9: present \\
\hline WINGPETCOL & Wing petal color & $\begin{array}{l}\text { Wing petal color taken on newly opened flowers. } \\
\text { 1: purple; } 2 \text { : white; } 3 \text { : light purple }\end{array}$ \\
\hline STREAKINT & Intensity of streaks & $\begin{array}{c}\text { Intensity of streaks on standard petal } \\
0 \text { : absent; } 3 \text { : slim : 5: moderate; } 7 \text { : intense }\end{array}$ \\
\hline PODANGLE & Pod angle & $\begin{array}{l}\text { Pod angle / attitude at maturity on the second or third pod bearing node. } \\
\qquad 1 \text { : very weak; } 3 \text { : weak; 5: medium; } 7: \text { high }\end{array}$ \\
\hline COLORPOD & Color green of pod & 3: weak; 5: medium; 7: high \\
\hline PODHIGHT & Pod height & $\begin{array}{l}\text { Height of the lowest pod } \\
\qquad \mathrm{cm}\end{array}$ \\
\hline PODWIDTH & Pod width & $\begin{array}{l}\text { Pod width in mature pods from the lowest insertion point on the primary } \\
\text { inflorescence } \\
\mathrm{cm}\end{array}$ \\
\hline $\begin{array}{l}\text { DAYSEMER- } \\
\text { GENCE }\end{array}$ & Seedling emergence & Number of days from sowing to first observed leaf. \\
\hline DAYSFLOWER & Days of flower & Number of days from sowing to first observed flower. \\
\hline PODMAT & Pod maturity & Days from sowing until $90 \%$ of the pods have dried. \\
\hline \multicolumn{3}{|r|}{ Yield components traits } \\
\hline TOTALWEIGHT & Plant weight & g \\
\hline PODPLANT & Pods per plant & count \\
\hline WEIGHTPOD & Weight of 10 pods & g \\
\hline SEEDSPOD & Seeds per 10 pods & Count: Average number of seeds per pod \\
\hline WGHTSEEDPOD & Weight of seed by 10 pods & g \\
\hline SEEDCOLOR & Color of seed & 1: beige; 2 : green; 3 : purple; 4: violet-brown \\
\hline SEEDSHAPE & Seed shape & 1: circular 2: elliptical; 3 : irregular \\
\hline HILUMCOLOR & Hilium color & $\begin{array}{l}\text { Color of hilum of mature seed. } \\
\text { 0: colorless; 1: black }\end{array}$ \\
\hline SEEDWGT & 100 Seeds weight & $\mathrm{g}$ \\
\hline
\end{tabular}




\section{Results and Discussion}

\section{Pheno-Morphological Characterization of Faba Bean Populations}

The survey of phenological growth stages revealed significant differences among studied faba bean populations in terms of seedling emergence date $(p<0.001)$, flowering $(p<0.001)$ and pod maturity $(\mathrm{p}<0.05)$ periods (Table 3$)$. The timing of seedling emergence averages varied from 9.67 days (Populations $V f 14, \quad V f 18$ and $V f 23)$ to 15 days after sowing (Populations $V f 6, V f 8, V f 11, V f 15, V f 19$ and $V f 22$ ).

Flowering period averages ranged from 48.67 days (Population Vf2) to 100.33 days (Population Vf22). Whereas, averages of pod maturity period varied from 95 days for $V f 2$ to 120.67 days for $V f 22$.

These values show that our populations are later than those evaluated by [29] with flowering days ranging from 33 to 78 days.

Descriptive statistics (min, max, average and variances) of the agro-morphological parameters assessed were presented in Table 4. Significant differences $(p<0.05)$ were identified among the 23 populations for all morphological traits. These results largely correspond to those found by [29] for a similar study on faba bean genotypes for the same traits.

The population $V f 23$ had the lowest coefficient of variation, $9.25 \%$ and $8.12 \%$, respectively for the number of flowers by inflorescence and Plant height at maturity with values greater than the average recorded; while the population $V f 20$ showed the highest number of stems per plant (12.86 stems), Leaflet length $(14.47 \mathrm{~cm})$ and Pod height $(13 \mathrm{~cm})$.

The population $V f 22$ exhibited the highest average of Plant height at maturity $(143.25 \mathrm{~cm})$. However, Vf6 had the lowest average among the populations studied. On the other hand, the average Plant height of all populations $(122.24 \mathrm{~cm})$ was lower than that recorded by [29] $(139.5 \mathrm{~cm})$. Variations, in terms of pod width, were $37.71 \%$ lower for $V f 16$ compared with $V f 7$ which recorded an average of $1.75 \mathrm{~cm}$. while nodes number per stem varied from 19.40 to 27.86 obtained for $V f 6$ and $V f 13$, respectively.

The lowest coefficient of variation was observed for Plant height at maturity with the population Vf20 (4.17\%), while the Pod width and Pod height parameters showed the most important variability represented by the population $V f 8$ with $\mathrm{CV}=67.59 \%$ and $\mathrm{CV}=87.18 \%$, respectively.

The averages of pod lengths $(9.43 \mathrm{~cm})$ were higher than those recorded in cultivar NEB404 from Beja $(7.86 \mathrm{~cm})$ [15] while those of number of seeds per pod (3.19 seeds) measured for the studied populations are similar to those found by [15] in the local Beja commercial cultivar (3 seeds) and the local cultivar "Hara" from Kef (2.9 seeds).

The different qualitative traits were shown in Fig. 1. The majority of populations exhibited the
Table 3. Pheno-morphological traits of the studied Vicia faba var minor populations.

\begin{tabular}{|c|c|c|c|}
\hline $\begin{array}{l}\text { Popula- } \\
\text { tions }\end{array}$ & $\begin{array}{l}\text { DAYS-EMER- } \\
\text { GENCE }\end{array}$ & $\begin{array}{c}\text { DAYSFLOW- } \\
\text { ER }\end{array}$ & PODMAT \\
\hline$V f 1$ & $13.67^{\mathrm{bc}}$ & $76.33^{\text {b-e }}$ & $110.33^{\mathrm{a}-\mathrm{d}}$ \\
\hline$V f 2$ & $10.33^{\mathrm{a}}$ & $48.67^{a}$ & $95,00^{a}$ \\
\hline$V f 3$ & $11.00^{\mathrm{ab}}$ & $76.67^{\text {be }}$ & $100.00^{\mathrm{a}-\mathrm{c}}$ \\
\hline Vf4 & $12.33^{\mathrm{a}-\mathrm{c}}$ & $65.00^{\mathrm{a}-\mathrm{c}}$ & $104.67^{\mathrm{a}-\mathrm{d}}$ \\
\hline$V f 5$ & $12.33^{\mathrm{a}-\mathrm{c}}$ & $77.33^{\text {b-e }}$ & $115.33^{\mathrm{b}-\mathrm{d}}$ \\
\hline Vf6 & $15.00^{c}$ & $82.67^{\mathrm{c}-\mathrm{f}}$ & $112.67^{\mathrm{a}-\mathrm{d}}$ \\
\hline Vf7 & $12.33^{\mathrm{a}-\mathrm{c}}$ & $66.00^{\mathrm{a}-\mathrm{c}}$ & $102.33^{\mathrm{a}-\mathrm{d}}$ \\
\hline$V f 8$ & $15.00^{c}$ & $93.33^{\mathrm{d}-\mathrm{f}}$ & $111.33^{\mathrm{a}-\mathrm{d}}$ \\
\hline$V f 9$ & $13.67^{\mathrm{bc}}$ & $96.33^{\text {ef }}$ & $117.67^{\mathrm{cd}}$ \\
\hline Vf10 & $13.67^{\mathrm{bc}}$ & $79.67^{\mathrm{b}-\mathrm{f}}$ & $102.33^{\mathrm{a}-\mathrm{d}}$ \\
\hline Vf11 & $15.00^{\mathrm{c}}$ & $91.00^{\mathrm{d}-\mathrm{f}}$ & $107.00^{\mathrm{a}-\mathrm{d}}$ \\
\hline Vf12 & $13.67^{\mathrm{bc}}$ & $60.67^{\mathrm{a}-\mathrm{c}}$ & $96.33^{\mathrm{ab}}$ \\
\hline Vf13 & $12.33^{\mathrm{a}-\mathrm{c}}$ & $75.33^{\text {b-e }}$ & $96.33^{\mathrm{ab}}$ \\
\hline Vfl4 & $9.67^{\mathrm{a}}$ & $74.67^{\text {be }}$ & $110.67^{\mathrm{a}-\mathrm{d}}$ \\
\hline Vf15 & $15.00^{\mathrm{c}}$ & $73.33^{\mathrm{b}-\mathrm{d}}$ & $98.67^{\mathrm{a}-\mathrm{c}}$ \\
\hline Vf16 & $12.33^{\mathrm{a}-\mathrm{c}}$ & $64.00^{\mathrm{a}-\mathrm{c}}$ & $98.67^{\mathrm{a}-\mathrm{c}}$ \\
\hline$V f 17$ & $13.67^{\mathrm{bc}}$ & $82.67^{\mathrm{c}-\mathrm{f}}$ & $115.33^{\mathrm{b}-\mathrm{d}}$ \\
\hline$V f 18$ & $9.67^{\mathrm{a}}$ & $60.00^{\mathrm{ab}}$ & $96.33^{\mathrm{ab}}$ \\
\hline Vf19 & $15.00^{\mathrm{c}}$ & $82.00^{\mathrm{b}-\mathrm{f}}$ & $109.00^{\mathrm{a}-\mathrm{d}}$ \\
\hline Vf20 & $11.00^{\mathrm{ab}}$ & $89.67^{\mathrm{d}-\mathrm{f}}$ & $108.33^{\mathrm{a}-\mathrm{d}}$ \\
\hline$V f 21$ & $12.33^{\mathrm{a}-\mathrm{c}}$ & $80.67^{\mathrm{b}-\mathrm{f}}$ & $108.33^{\mathrm{a}-\mathrm{d}}$ \\
\hline$V f 22$ & $15.00^{\mathrm{c}}$ & $100.33^{\mathrm{f}}$ & $120.67^{\mathrm{d}}$ \\
\hline$V f 23$ & $9.67^{\mathrm{a}}$ & $82.00^{\mathrm{b}-\mathrm{f}}$ & $107.00^{\mathrm{a}-\mathrm{d}}$ \\
\hline ANOVA & $3.96 * * *$ & $3.67 * * *$ & $1.68 *$ \\
\hline
\end{tabular}

ANOVA test is represented by $\mathrm{F}$ values followed by significance levels: ns $(P \geq 0.05),{ }^{*}(P<0.05), * *(P<0.01)$ and *** $(P<0.001)$; mean values are followed by Duncan post-hoc multirange groups.

medium green leaf color intensity with an intermediate leaf shape, a very weak pod angle and a black melanin color.

All populations presented anthocyanin pigmentation, medium green stem color, weak green pod color, and indeterminate growth.

The intensity of streaks in faba bean flowers was rather absent, slight, moderate or intense. The highest percentage of slight and moderate streaks was about $62.5 \%$ presented by $V f 9$ and $\mathrm{Vf} 8$, respectively. While, $V f 11$ showed the highest percentage of intense streaks with $71.4 \%$.

The color of petals was light purple for most populations except $V f 13, V f 15, V f 19$ with $100 \%$ purple 

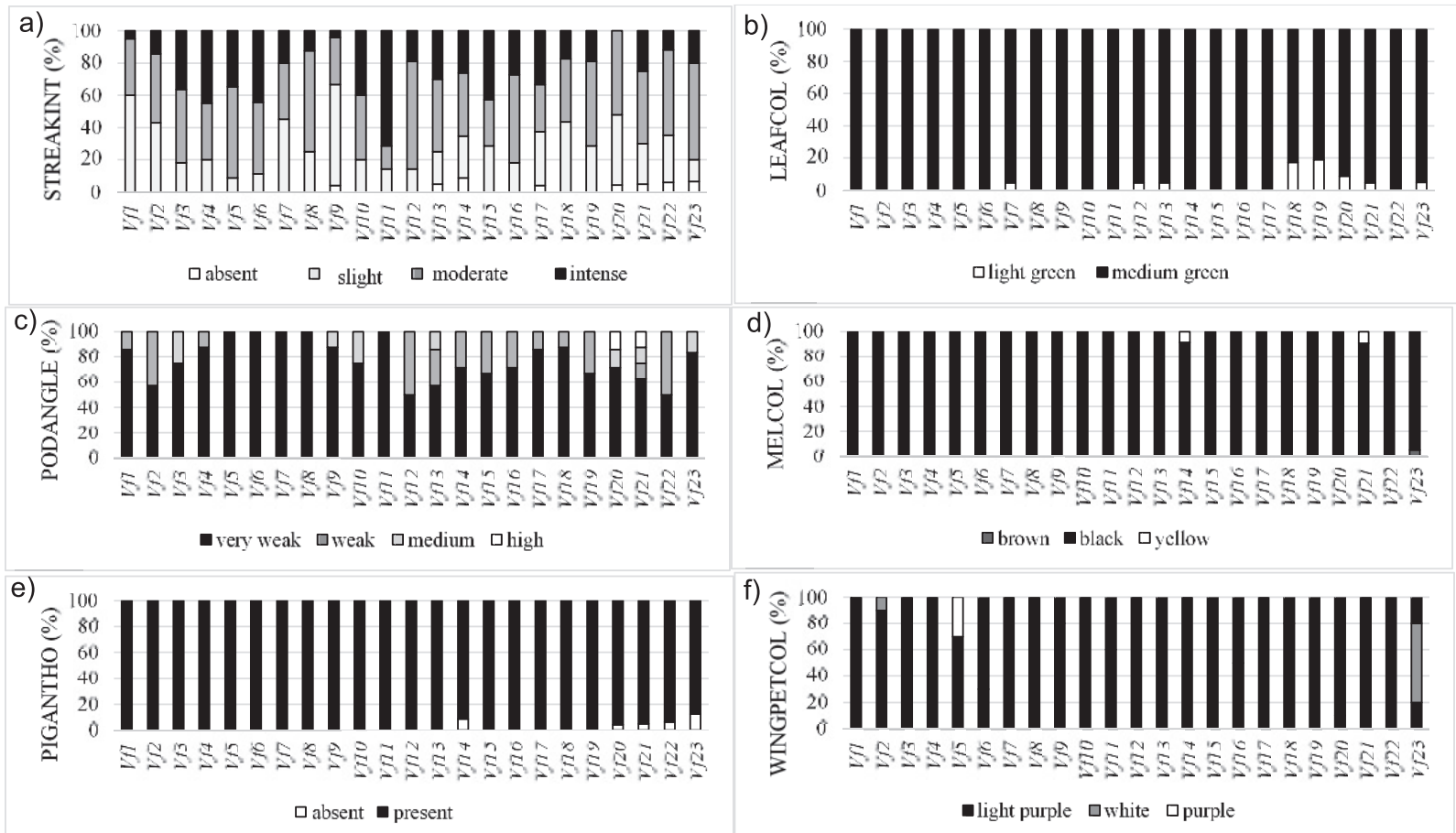

Fig. 1. Qualitative morphological traits of the studied Vicia faba var minor populations; a) Intensity of streaks; b) Color of leaflet; c) Pod angle; d) Melanin color; e) Anthocyanin pigmentation; f) Wing petal color.

petals and $V f 22$ with $100 \%$ of white petals. According to [30], the variations in this trait (WINGPETCOL) are correlated with some chemical components such as tannin, phenolics, etc. and could be considered as an indicator to classify faba bean genotypes.

Agro-morphological traits have been considered by several researchers $[15,31-33]$ as the most commonly used tool for breeding and assessment of genetic resources in many countries.

Matrix of correlation (Table 7) showed different levels of significance between traits. Moderately high positive associations were detected between traits. To avoid spurious significant results due to the examination of a large number of correlations, only the correlations with $p<0.05$ were given.

Therefore, the highest positive correlations were detected for pod width with pod height (0.855) and stem number (0.797), followed by the correlation between days of flowering and pod maturity (0.784). Negative correlations were significant between days of seedling emergence and leaflet length (-0.649), number of flowers per inflorescence $(-0.586)$ and node numbers $(-0.430)$.

\section{Yield Compounds of Faba Bean Populations}

Six quantitative yield components traits were assessed and the results are presented in Table 5. High significant variability among populations for all traits $(\mathrm{p}<0.001)$ was obtained. The highest coefficient of variation $(34.72 \%)$ was observed for the number of pods per plant followed by the total weight of plant (33.75\%); and the 100 seed weight showed the lowest coefficient of variation $(10.32 \%)$.

The number of pods were determined and weighted on the basis of a single plant. The averages ranged from 33.23 to 171 pods/plant and producing from 87.27 to $500.78 \mathrm{~g} /$ plant for $V f 22$ and $V f 23$, respectively. Pod characteristics were assessed on the basis of 10 pods and related results revealed that highest averages were obtained by $V f 20$ for a weight of 10 pods (54.96 g), the number of seeds (43.57 seeds/10pods) and weight of seeds (44.25 g). Weight of 100 seeds varied from $80.17 \mathrm{~g}$ to $130.71 \mathrm{~g}$ which recorded for $V f 22$ and $V f 8$ respectively. Our results are in agreement with those reported by [18] who ranged the values from 42.70 (Saber 02 commercial cultivar to 106.40 g per 100 seeds for the cultivar NEB 404.

Within-population variability revealed that the most homogenous population was $V f 18$ presenting the lowest CV $(<10 \%)$ for the six yield components traits (Table 5).

Table 7 shows that the most significant correlations were between the weight of pods and those of seeds per pod $(\mathrm{r}=0.991)$, as well as between the number of pods per plant and the total weight $(\mathrm{r}=0.963)$.

Three qualitative yield components were assessed (Fig. 2). Related results revealed that the majority of the populations had black hilum and elliptic shape of seed. While Vf5, Vf12, Vf13 and Vf22 were the most homogenous populations regarding seed color with $100 \%$ of violet-brown seeds, while Vfl4 exhibited 100\% of beige seed color. 


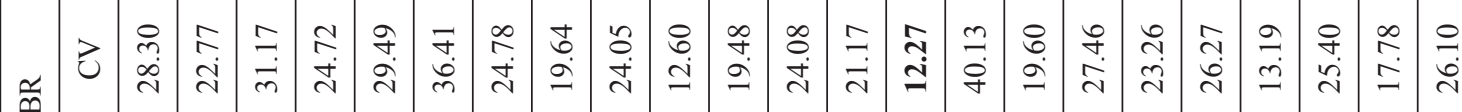

วิ

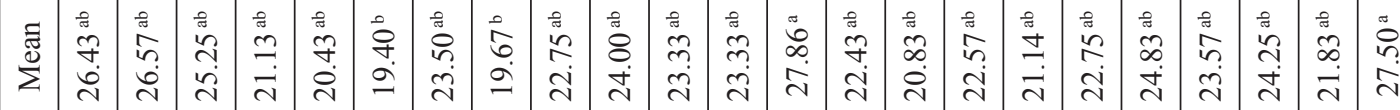

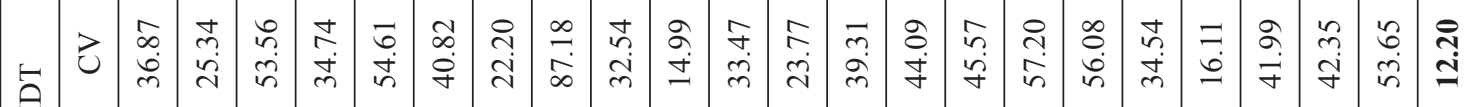

○ิ

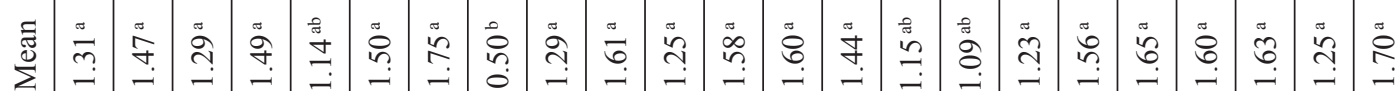

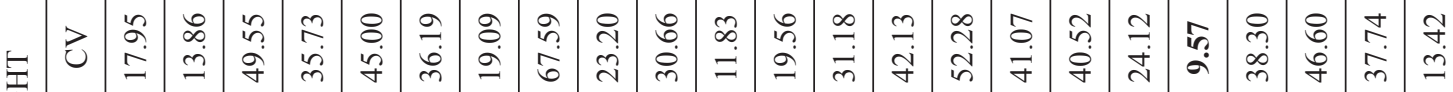

Oิ

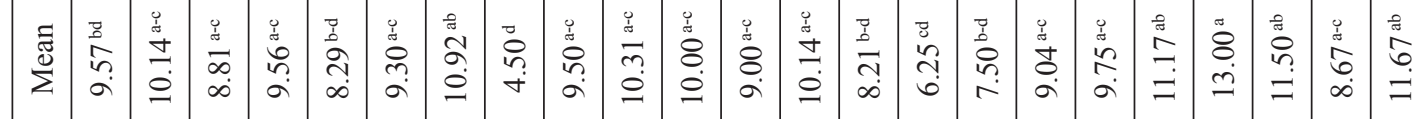

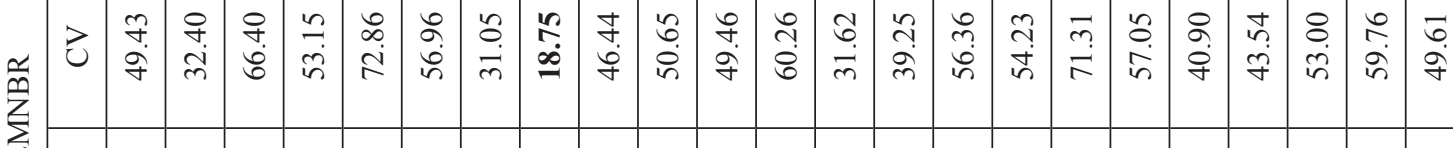

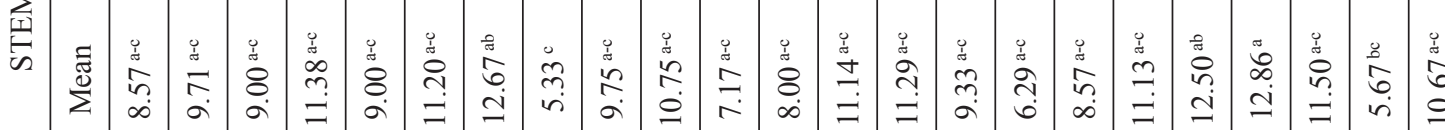

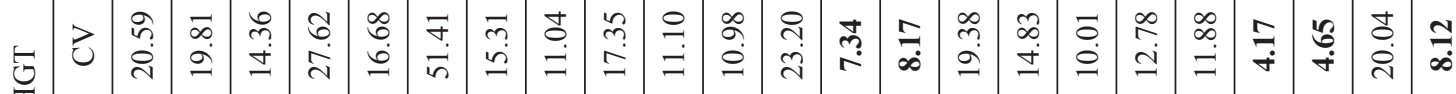
案

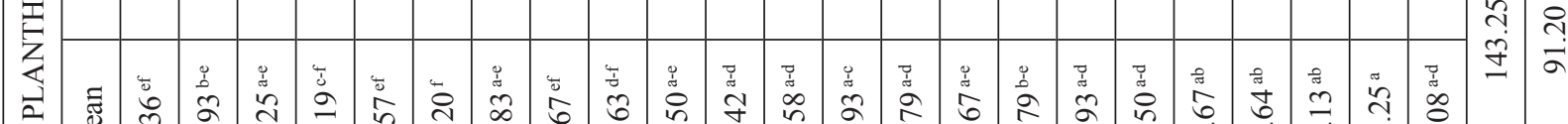

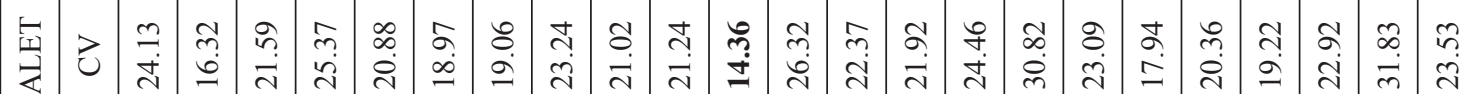
过

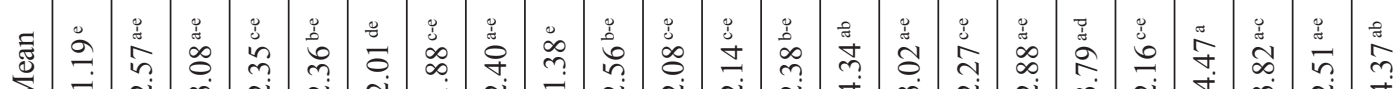

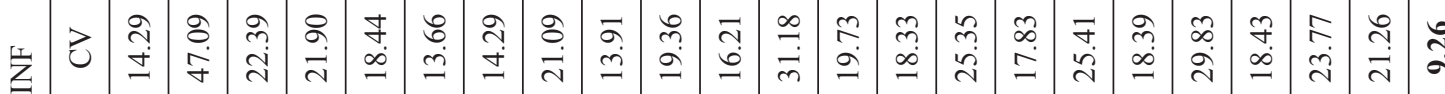

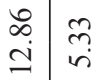

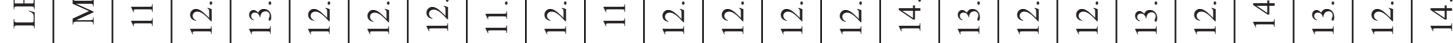

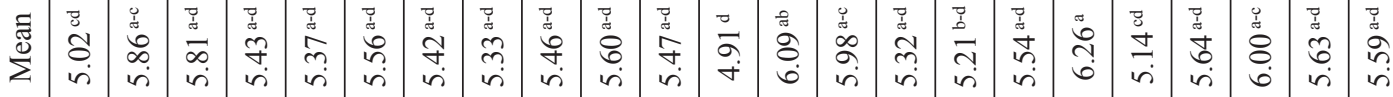

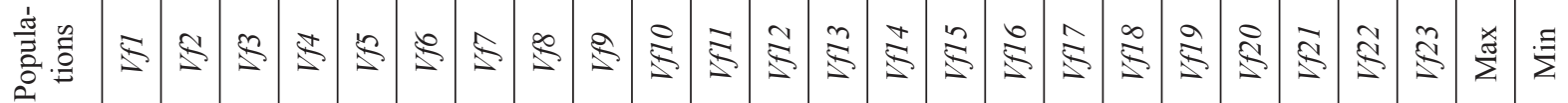




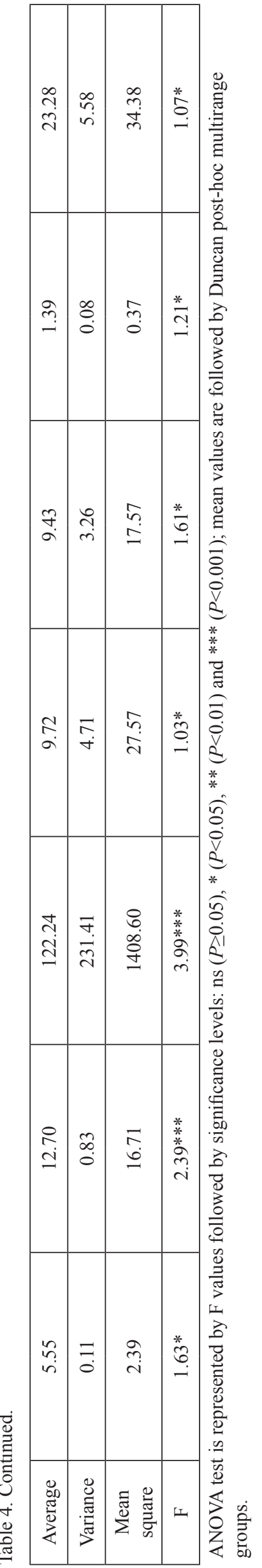




\begin{tabular}{|c|c|c|c|c|c|c|c|c|c|c|c|c|c|c|c|c|}
\hline $\begin{array}{l}8 \\
0\end{array}$ & $\begin{array}{l}\vec{\sigma} \\
\dot{m}\end{array}$ & $\begin{array}{l}\vec{b} \\
\dot{m}\end{array}$ & $\overrightarrow{\vec{r}}$ & $\begin{array}{l}\underset{n}{n} \\
i n\end{array}$ & $\underset{m}{ \pm}$ & $\stackrel{m}{m}$ & 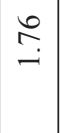 & $\begin{array}{l}8 \\
\text { in }\end{array}$ & ô. & $\begin{array}{l}\ddot{c} \\
\dot{m}\end{array}$ & 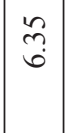 & $\begin{array}{l}0 \\
0 \\
0\end{array}$ & ণิ & $\hat{a}$ & & 苂 \\
\hline 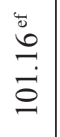 & 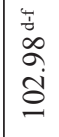 & 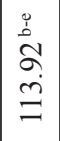 & $\begin{array}{l}0 \\
0 \\
0 \\
0 \\
0 \\
0 \\
0\end{array}$ & 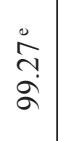 & 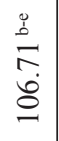 & $\begin{array}{l}0 \\
8 \\
0 \\
0 \\
0 \\
= \\
=\end{array}$ & $\begin{array}{l}: \\
\stackrel{0}{a} \\
\alpha\end{array}$ & $\begin{array}{l}\vec{\sim} \\
\infty \\
\stackrel{\infty}{=}\end{array}$ & 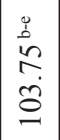 & 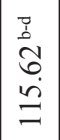 & $\begin{array}{c}\stackrel{1}{1} \\
\dot{0} \\
\infty\end{array}$ & $\underset{+}{\stackrel{d}{\infty}}$ & & & & $\vec{n}$ \\
\hline $\begin{array}{l}\infty \\
\stackrel{0}{0} \\
\dot{0}\end{array}$ & $\begin{array}{r}\tilde{m} \\
\ddot{n}\end{array}$ & $\stackrel{\curvearrowright}{\dot{r}}$ & $\frac{\vec{r}}{\dot{r}}$ & $\begin{array}{c}\stackrel{0}{1} \\
\infty \\
\infty\end{array}$ & $\begin{array}{l}\stackrel{2}{i} \\
i \vec{i}\end{array}$ & $\frac{5}{6}$ & $\stackrel{\substack{+i}}{ }$ & $\begin{array}{l}\hat{0} \\
0 \\
0\end{array}$ & $\stackrel{0}{\stackrel{0}{r}}$ & $\vec{n}$ & $\stackrel{\stackrel{\Upsilon}{\Xi}}{=}$ & $\vec{\sigma}$ & & & & \\
\hline 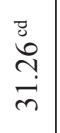 & 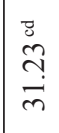 & $\mid \begin{array}{c}0 \\
0 \\
o \\
\dot{m} \\
\dot{m}\end{array}$ & $\begin{array}{l}0 \\
\stackrel{0}{n} \\
\hat{n} \\
\dot{m}\end{array}$ & 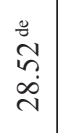 & $\begin{array}{l}\vec{s} \\
\stackrel{\vec{c}}{ } \\
\vec{m}\end{array}$ & $\begin{array}{l}\vec{D} \\
\vec{\sigma} \\
\dot{m}\end{array}$ & 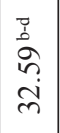 & $\begin{array}{l}\stackrel{0}{\tilde{c}} \\
\stackrel{0}{0} \\
\vec{j}\end{array}$ & $\begin{array}{l}\tilde{\sim} \\
\tilde{y} \\
\dot{y}\end{array}$ & 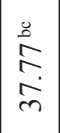 & 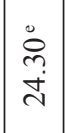 & $\begin{array}{l}\vec{s} \\
\stackrel{\infty}{a} \\
\stackrel{m}{m}\end{array}$ & & & & \\
\hline $\begin{array}{l}\dot{D} \\
\dot{i n}\end{array}$ & $\begin{array}{l}\infty \\
\stackrel{+}{+}\end{array}$ & $\begin{array}{c}\tilde{n} \\
\tilde{m} \\
\dot{m}\end{array}$ & $\begin{array}{l}\stackrel{0}{0} \\
i\end{array}$ & $\begin{array}{c}\hat{m} \\
i n\end{array}$ & $\stackrel{\text { mे }}{+}$ & 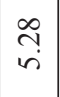 & $\stackrel{\hat{\sigma}}{-}$ & $\begin{array}{l}n \\
0 \\
i n\end{array}$ & $\begin{array}{l}n \\
\text { in }\end{array}$ & $\begin{array}{l}\hat{b} \\
i\end{array}$ & $\tilde{\alpha}$ & 芦 & & & & \\
\hline 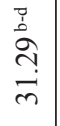 & $\begin{array}{l}r \\
\dot{b} \\
\hat{n} \\
\tilde{e} \\
0\end{array}$ & 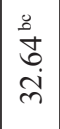 & 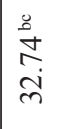 & $\begin{array}{l}\vec{j} \\
\stackrel{\vec{d}}{\sim} \\
\end{array}$ & $\begin{array}{l}\bar{b} \\
\bar{a} \\
\vec{\lambda}\end{array}$ & $\begin{array}{l}\vec{z} \\
\stackrel{8}{0} \\
0 \\
\dot{0} \\
\end{array}$ & 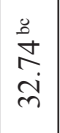 & $\begin{array}{l}8 \\
0 \\
0 \\
0 \\
m \\
m\end{array}$ & 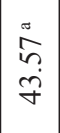 & 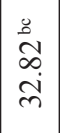 & 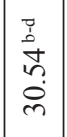 & $\frac{\infty}{\infty}$ & & & & $\therefore$ \\
\hline$\underset{0}{\stackrel{R}{0}}$ & $\underset{+}{\stackrel{+}{+}}$ & $\vec{m}$ & $\stackrel{?}{\stackrel{r}{r}}$ & $\begin{array}{c}\stackrel{a}{a} \\
\infty\end{array}$ & $\begin{array}{l}\stackrel{R}{i} \\
i\end{array}$ & $\begin{array}{l}\hat{b} \\
\dot{i}\end{array}$ & 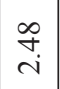 & $\stackrel{\Xi}{=}$ & $\stackrel{n}{m}$ & $\begin{array}{l}\infty \\
m \\
m\end{array}$ & 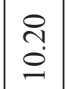 & 志 & & & & \\
\hline $\begin{array}{l}\dot{j} \\
\stackrel{n}{n} \\
\stackrel{m}{ }\end{array}$ & 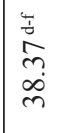 & $\begin{array}{l}0 \\
\dot{d} \\
\bar{a} \\
\dot{b}\end{array}$ & 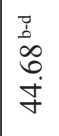 & 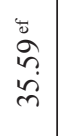 & $\begin{array}{l}\dot{8} \\
\vec{b} \\
\dot{q} \\
\end{array}$ & 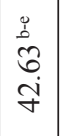 & $\begin{array}{l}\dot{D} \\
\dot{m} \\
\stackrel{7}{F} \\
\vec{F}\end{array}$ & 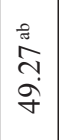 & 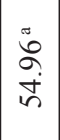 & 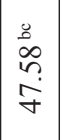 & $\begin{array}{c}\infty \\
\stackrel{\infty}{1} \\
\dot{m}\end{array}$ & 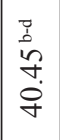 & & & & m. \\
\hline $\begin{array}{l}8 \\
\stackrel{\dot{2}}{ }\end{array}$ & $\stackrel{\widetilde{N}}{ \pm}$ & $\begin{array}{l}\hat{b} \\
i \\
\mathcal{I}\end{array}$ & $\stackrel{n}{\circ}$ & $\begin{array}{l}\vec{\infty} \\
\stackrel{\omega}{ }\end{array}$ & $\stackrel{0}{\check{\Xi}}$ & $\begin{array}{l}m \\
i \\
n\end{array}$ & $\underset{\infty}{\stackrel{2}{\infty}}$ & $\begin{array}{l}\stackrel{n}{\infty} \\
\stackrel{\infty}{-}\end{array}$ & $\begin{array}{l}\infty \\
\infty \\
0 \\
0 \\
0\end{array}$ & $\frac{n}{\stackrel{c}{c}}$ & $\underset{\hat{v}}{\stackrel{r}{v}}$ & 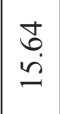 & & & & \\
\hline 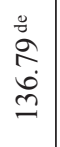 & 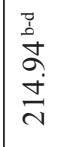 & 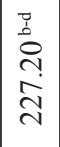 & $\mid \begin{array}{l}\vec{j} \\
\stackrel{d}{\sim} \\
\tilde{a} \\
\stackrel{d}{\sim}\end{array}$ & 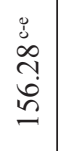 & 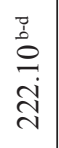 & $\begin{array}{l}\vec{D} \\
\vec{b} \\
\dot{\lambda} \\
\vec{\lambda}\end{array}$ & 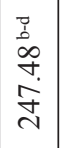 & 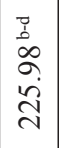 & 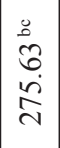 & 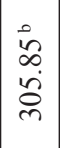 & $\begin{array}{l}0 \\
\hat{1} \\
\stackrel{\infty}{\infty}\end{array}$ & $\begin{array}{l}\infty \\
\infty \\
\\
\dot{8} \\
i n\end{array}$ & & & & $\underset{\forall}{+}$ \\
\hline $\begin{array}{l}\tilde{\sim} \\
\stackrel{n}{n}\end{array}$ & $\begin{array}{l}\hat{\infty} \\
\dot{\emptyset}\end{array}$ & $\begin{array}{c}\tilde{\sigma} \\
\dot{m}\end{array}$ & $\begin{array}{l}\infty \\
\infty \\
0\end{array}$ & $\begin{array}{l}\infty \\
\stackrel{\infty}{+} \\
\dot{ \pm}\end{array}$ & 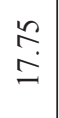 & $\begin{array}{l}\vec{m} \\
\stackrel{m}{n}\end{array}$ & $\stackrel{0}{\sim}$ & $\underset{\dot{\vec{v}}}{\overrightarrow{\dot{v}}}$ & 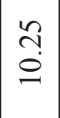 & $\begin{array}{l}\partial \\
\stackrel{g}{c}\end{array}$ & $\begin{array}{l}\infty \\
\stackrel{+}{\sim} \\
\dot{d}\end{array}$ & $\begin{array}{l}\hat{n} \\
\stackrel{n}{6} \\
-\end{array}$ & & \multirow{2}{*}{ 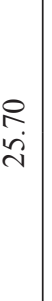 } & & \multirow{2}{*}{ 蒋 } \\
\hline $\begin{array}{l}\frac{n}{\tilde{n}} \\
\tilde{y} \\
\dot{7}\end{array}$ & 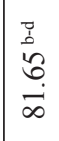 & $\mid \begin{array}{l}0 \\
\dot{0} \\
0 \\
0 \\
\dot{0} \\
\dot{0}\end{array}$ & $\begin{array}{l}0 \\
0 \\
\sigma \\
\infty \\
\infty \\
\infty\end{array}$ & $\begin{array}{l}\dot{\dot{d}} \\
\tilde{a} \\
i \\
\tilde{n}\end{array}$ & $\begin{array}{l}\frac{D}{b} \\
\stackrel{2}{a} \\
\stackrel{i}{i}\end{array}$ & $\begin{array}{l}0 \\
\dot{0} \\
\dot{0} \\
\dot{0}\end{array}$ & $\begin{array}{l}0 \\
0 \\
\cdots \\
m \\
\infty \\
\infty\end{array}$ & $\begin{array}{l}0 \\
\dot{b} \\
0 \\
n \\
i \\
i \\
i\end{array}$ & $\begin{array}{l}\dot{0} \\
\bar{\partial} \\
\dot{\sigma}\end{array}$ & $\begin{array}{l}\dot{ \pm} \\
\dot{\sigma}\end{array}$ & $\begin{array}{l}\dot{m} \\
\ddot{m} \\
m\end{array}$ & $\frac{\stackrel{8}{8}}{\stackrel{\Xi}{\Xi}}$ & & & $\dot{d}$ & \\
\hline $\overrightarrow{\vec{J}}$ & 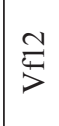 & $\mid \begin{array}{l}m \\
\vec{p} \\
>\end{array}$ & $\underset{>}{\stackrel{0}{c}}$ & $\stackrel{n}{a}$ & $\begin{array}{l}0 \\
\stackrel{1}{>}\end{array}$ & $\stackrel{\vec{M}}{>}$ & 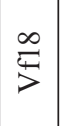 & 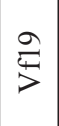 & 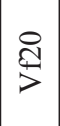 & $\stackrel{\vec{g}}{>}$ & 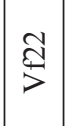 & $\stackrel{\tilde{d}}{>}$ & 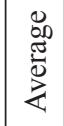 & is & $\frac{\partial}{\partial}$ & 山 \\
\hline
\end{tabular}




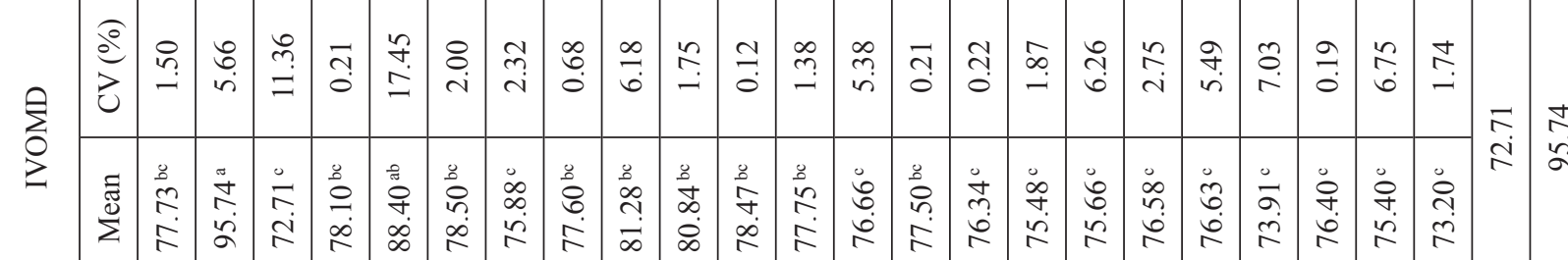

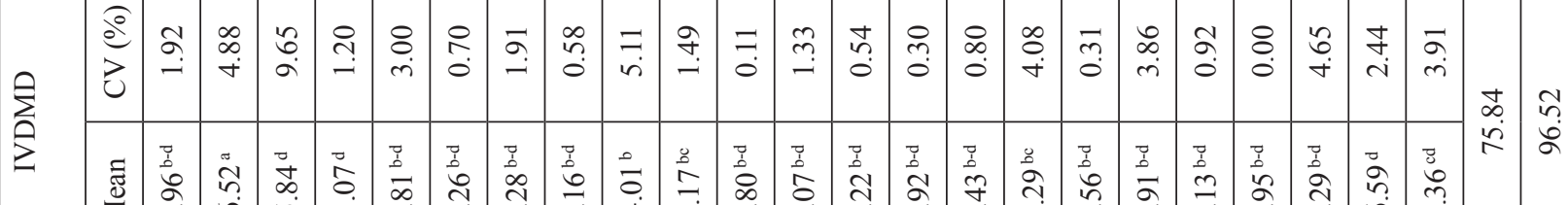

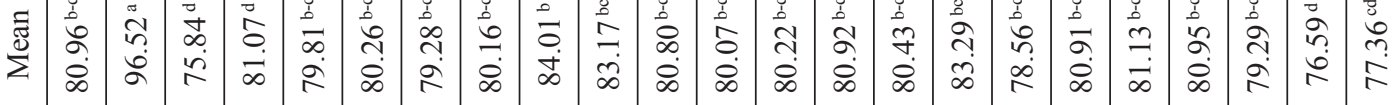

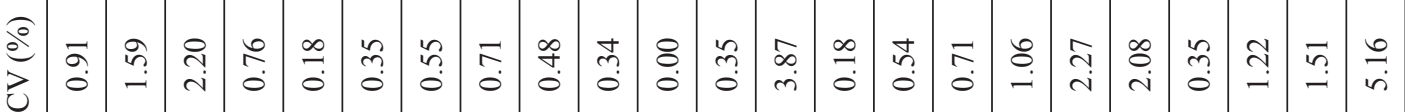

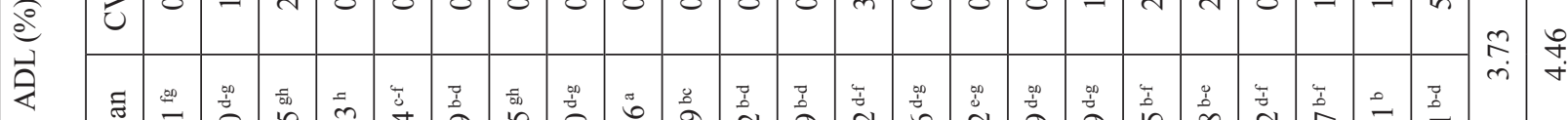

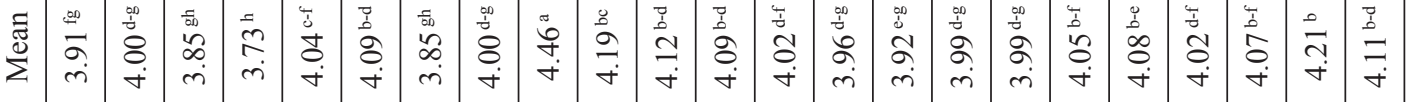

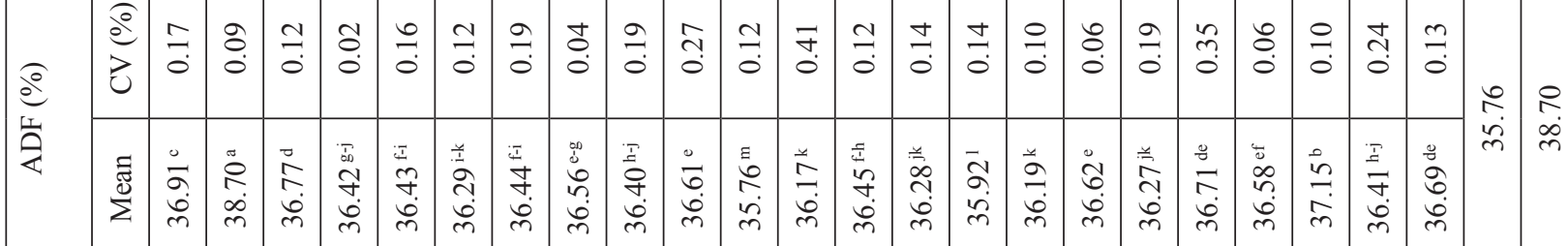

๑)

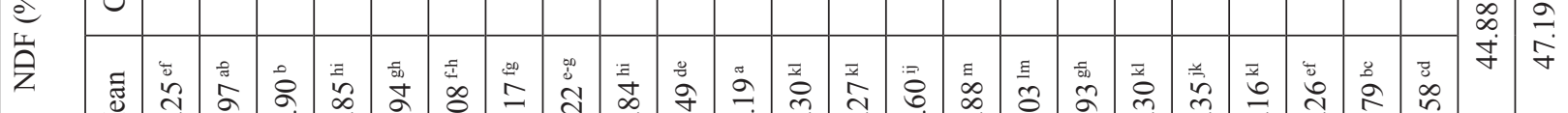

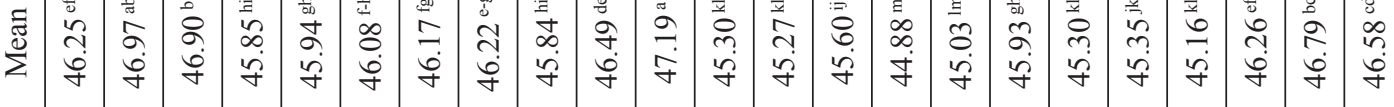

0
0
0
0
0
0
0
0
0
0
0
0
0
0
0
0
0
0
0
0
0

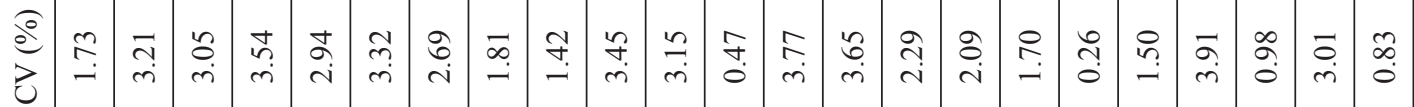

₹

卷

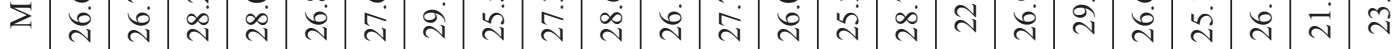

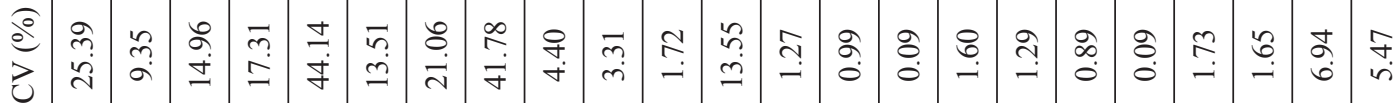

茙

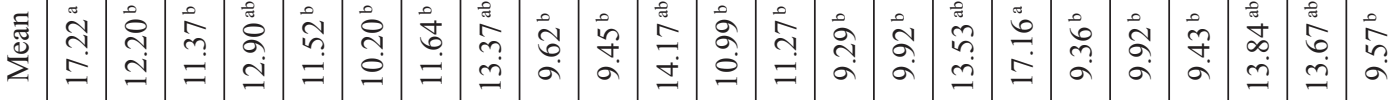

䒿

:

宸

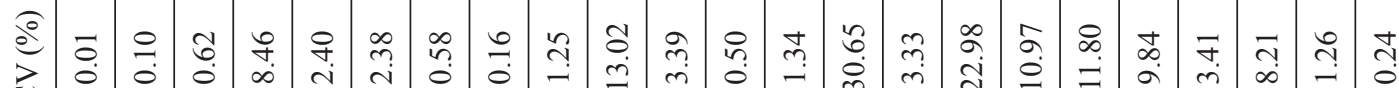

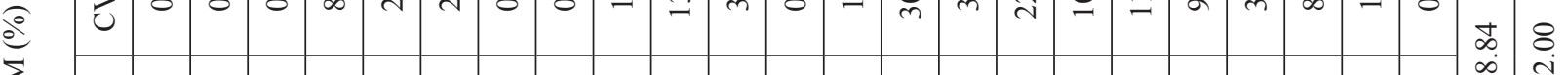

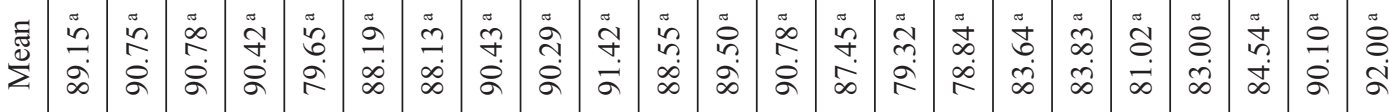

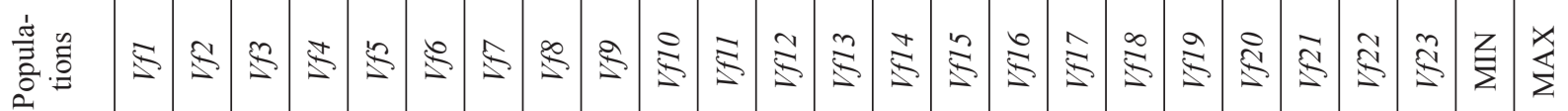




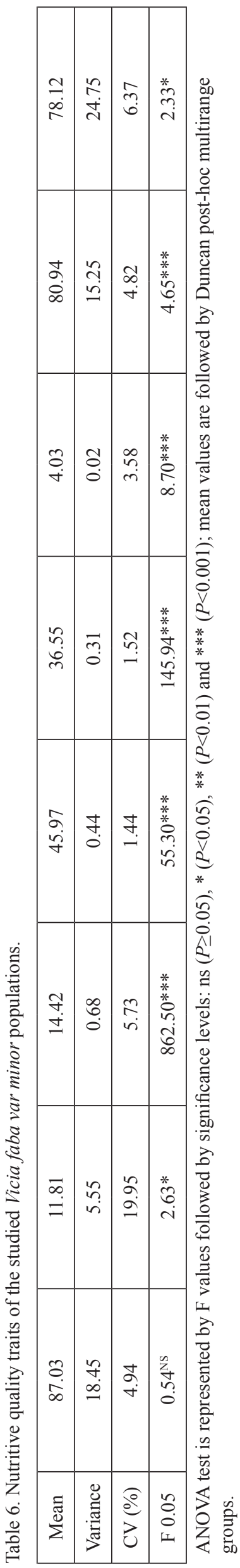

The significant variability observed among faba beans populations could offer an important genetic basis for plant breeders to develop high yields of faba bean genotypes under marginal environmental conditions [32, 34-36].

Although morphological and agronomic traits are commonly used to access genetic diversity, they are not sufficient to cover the genome, they are affected by environmental factors and they depend on the stage of development [29]. In fact, studied populations showed no significant correlation (with $r=0.181$ ) of total weight with flowering date (negative). However, the studies of [23] reported positive correlation between the yield and the whole flowering period.

In the line of the present study, Vf23 produced the highest yield value and high value of plant weight between populations and highest number of pods per plant. As reported in [37], phenotypic and genotypic correlations between seed yield and number of pods per plant were positive and significant; this result is similar to the aforementioned current study and the population Vf23 proves this point. This indicates that the selection based on seeds per pod increases seed yield. In the current research, the practice of selecting the next generation will be very successful through selection based on seeds per pod and the number of pods per plant.

The populations $V f 14, V f 18, V f 21$ and $V f 23$ showed high performance in arid oasis environments, so they are highly recommended to be used in breeding programs and released as synthetic varieties. Increasing yield is the main breeding goal of most faba bean crop improvement programs. The grain yield of faba beans depends on many related traits. Determining the degree and nature of the relationship between traits, especially the impact of each trait on yield, is the first step in selecting the best plant breeding components. The interrelationship between features helps to develop a multi-character selection scheme. The success of an inbred plant breeding program depends on the selection of the genotype that can produce offspring with the desired combination of traits. Like other crops, the yield of faba bean is a complex feature consisting of many interrelated morphological and physiological characteristics.

Plant height, number of stems and pods per plant, 100 -seed weight; days to flowering and maturity are the most important traits in faba bean improvement for increasing seed yield due to direct and indirect correlation with seed yield $[38,39]$.

Moreover, the relationship between agromorphological characteristics and the chemical composition of faba beans must be known and studied $[40,41]$ to better understand their effect on the determination of quality parameters in varieties adapted to local conditions $[16,42,43]$. 
Table 7. Correlations between agro morphological, yield components and nutritive quality traits of the studied Vicia faba var minor.

\begin{tabular}{|c|c|c|c|c|c|c|c|c|c|c|c|c|c|c|c|c|c|c|c|c|c|c|c|c|}
\hline Variables & 1 & 2 & 3 & 4 & 5 & 6 & 7 & 8 & 9 & 10 & 11 & 12 & 13 & 14 & 15 & 16 & 17 & 18 & 19 & 20 & 21 & 22 & & 24 \\
\hline 1 PODPLANT & 1 & & & & & & & & & & & & & & & & & & & & & & & \\
\hline 2 TOTALWEIGHT & 0.963 & 1 & & & & & & & & & & & & & & & & & & & & & & \\
\hline 3 WEIGHTPOD & 0.232 & 0.429 & 1 & & & & & & & & & & & & & & & & & & & & & \\
\hline 4 SEEDSPOD & 0.527 & 0.641 & 0.537 & 1 & & & & & & & & & & & & & & & & & & & & \\
\hline 5 WGHTSEEDPOD & 0.213 & 0.403 & 0.991 & 0.521 & 1 & & & & & & & & & & & & & & & & & & & \\
\hline 6 SEEDWGT & -0.204 & -0.110 & 0.555 & -0.376 & 0.583 & 1 & & & & & & & & & & & & & & & & & & \\
\hline $7 \mathrm{NDF}$ & 0.069 & 0.034 & -0.223 & -0.034 & -0.223 & -0.149 & 1 & & & & & & & & & & & & & & & & & \\
\hline $8 \mathrm{ADF}$ & 0.269 & 0.352 & 0.370 & 0.209 & 0.359 & 0.189 & 0.393 & 1 & & & & & & & & & & & & & & & & \\
\hline $9 \mathrm{ADL}$ & -0.022 & -0.010 & -0.076 & 0.200 & -0.099 & -0.280 & 0.108 & -0.083 & 1 & & & & & & & & & & & & & & & \\
\hline 10 IVDMD & -0.033 & 0.022 & 0.231 & 0.103 & 0.245 & 0.137 & 0.072 & 0.658 & 0.095 & 1 & & & & & & & & & & & & & & \\
\hline 11 IVOMD & -0.119 & -0.102 & 0.032 & -0.111 & 0.063 & 0.167 & 0.259 & 0.591 & 0.138 & 0.805 & 1 & & & & & & & & & & & & & \\
\hline $12 \mathrm{DM}$ & 0.175 & 0.118 & -0.160 & 0.118 & -0.135 & -0.189 & 0.613 & 0.247 & 0.134 & 0.059 & 0.057 & 1 & & & & & & & & & & & & \\
\hline 13 Ash & -0.340 & -0.287 & -0.177 & -0.441 & -0.208 & 0.215 & 0.323 & 0.148 & -0.262 & -0.067 & -0.008 & 0.009 & 1 & & & & & & & & & & & \\
\hline $14 \mathrm{CP}$ & -0.068 & -0.118 & 0.010 & -0.222 & 0.068 & 0.255 & -0.049 & -0.019 & -0.211 & 0.082 & 0.162 & 0.034 & -0.213 & 1 & & & & & & & & & & \\
\hline 15 FLWPERINF & 0.236 & 0.260 & 0.248 & 0.286 & 0.230 & -0.031 & 0.137 & 0.241 & 0.021 & 0.070 & 0.029 & 0.162 & -0.262 & 0.076 & 1 & & & & & & & & & \\
\hline 16 LENGTHLEALET & 0.565 & 0.586 & 0.352 & 0.570 & 0.331 & -0.177 & -0.130 & 0.057 & -0.124 & -0.178 & -0.286 & -0.157 & -0.376 & -0.174 & 0.585 & 1 & & & & & & & & \\
\hline 17 PLANTHGT & 0.239 & 0.248 & 0.178 & 0.478 & 0.139 & -0.374 & -0.189 & -0.060 & 0.140 & -0.197 & -0.399 & -0.097 & -0.199 & -0.257 & 0.337 & 0.564 & 1 & & & & & & & \\
\hline 18 STEMNBR & 0.337 & 0.390 & 0.499 & 0.536 & 0.523 & 0.025 & -0.261 & 0.151 & -0.153 & 0.064 & -0.046 & -0.062 & -0.524 & 0.442 & 0.350 & 0.335 & 0.226 & 1 & & & & & & \\
\hline 19 PODHIGHT & 0.349 & 0.431 & 0.406 & 0.751 & 0.398 & -0.296 & 0.119 & 0.272 & 0.139 & 0.060 & -0.066 & 0.115 & -0.192 & 0.074 & 0.252 & 0.257 & 0.454 & 0.697 & 1 & & & & & \\
\hline 20 PODWIDTH & 0.402 & 0.379 & 0.172 & 0.551 & 0.189 & -0.351 & -0.065 & 0.162 & 0.016 & 0.039 & -0.081 & 0.137 & -0.394 & 0.260 & 0.274 & 0.247 & 0.475 & 0.795 & 0.855 & 1 & & & & \\
\hline 21 NODNBR & 0.481 & 0.521 & 0.275 & 0.481 & 0.249 & -0.194 & 0.201 & 0.466 & 0.013 & 0.200 & 0.004 & 0.354 & -0.039 & -0.088 & 0.216 & 0.110 & 0.387 & 0.282 & 0.577 & 0.528 & 1 & & & \\
\hline 22 DAYSLIFTING & -0.677 & -0.680 & -0.343 & -0.552 & -0.321 & 0.169 & 0.028 & -0.351 & 0.257 & -0.179 & -0.076 & -0.076 & 0.315 & 0.023 & -0.586 & -0.649 & -0.256 & -0.412 & -0.357 & -0.394 & -0.430 & 1 & & \\
\hline 23 DAYSFLOWER & -0.261 & -0.181 & 0.009 & 0.095 & -0.020 & -0.072 & 0.225 & -0.347 & 0.523 & -0.487 & -0.359 & 0.104 & 0.079 & -0.358 & -0.078 & -0.021 & 0.044 & -0.231 & -0.031 & -0.317 & -0.231 & 0.488 & 1 & \\
\hline 24 PODMAT & -0.256 & -0.201 & -0.070 & -0.043 & -0.107 & -0.033 & 0.236 & -0.156 & 0.395 & -0.338 & -0.068 & -0.011 & 0.247 & -0.354 & -0.165 & -0.112 & -0.168 & -0.181 & -0.057 & -0.293 & -0.418 & 0.369 & 0.784 & 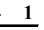 \\
\hline
\end{tabular}

\section{Chemical Composition and Nutritive Value of Faba}

Results related to the chemical composition of studied populations were shown in Table 6. With the exception of DM, analysis of variances revealed highly significant differences $(\mathrm{p}<0.05)$ among populations for the entire assessed traits. Variability determined by the coefficient of variation showed that the lowest value (1.44\%) was observed for the NDF followed by the ADF $(1.52 \%)$; while ASH exhibited the highest coefficient of variation $(19.95 \%)$.

Faba bean populations assessed by chemical composition presented averaged levels of DM and ash of about $87.03 \%$ and $11.81 \%$, receptively. The variation in mineral composition may be due to the soil composition, harvesting area, and the nature of the soil corresponding to each population in our study. Moreover, crude proteins contents varied from one population to another, they ranged from 21.99 (Vf22) to $29.60 \%$ (Vfl8) (Table 6). Our results are similar to those reported by several authors $[30,41]$ and it is in the global average of $29 \%$ mentioned by [44]. Compared with other pulses, such as pea, which have CP contents from 15 to $30 \%$ dry weight [45], it was found that Vicia faba var minor have acceptable levels [46]. On the other hand, compared to forages such as barley and straw which have low CP levels from 6 to $10 \%$, faba bean have the advantage of providing a ration richer in $\mathrm{CP}$, it can therefore be associated with these poor forages in nitrogen to relatively improve $\mathrm{CP}$ level in animal feed $[47,48]$. Furthermore, NDF averages varied from 44.88 (Vfl15) to $47.19 \%$ ( $V f 11)$ which is higher than that found for lucerne hay (41.4\%) by [49]. While the ADF averaged from 35.76 ( Vfl1) to $38.70 \%$ (Vf2)The lowest average of ADL was recorded by Vf4 $(3.73 \%)$ versus Vf9 which presented the highest mean value (4.46\%). Compared with the results reported by [49] on lucerne hay, our studied Vicia faba var minor populations represented higher rates of $\mathrm{ADF}$ and $\mathrm{ADL}$ than those of lucerne hay with respectively (29\%) and (0.9\%).

The average fiber content is higher than that found by [50], with NDF (12.6 to $16.5 \% \mathrm{DM}$ ) and $\mathrm{ADF}$ levels $(10.1$ to $13.7 \% \mathrm{DM})$. The high value can be explained by the climatic conditions of the cultivation of our faba bean. [30] mentioned that climatic factors
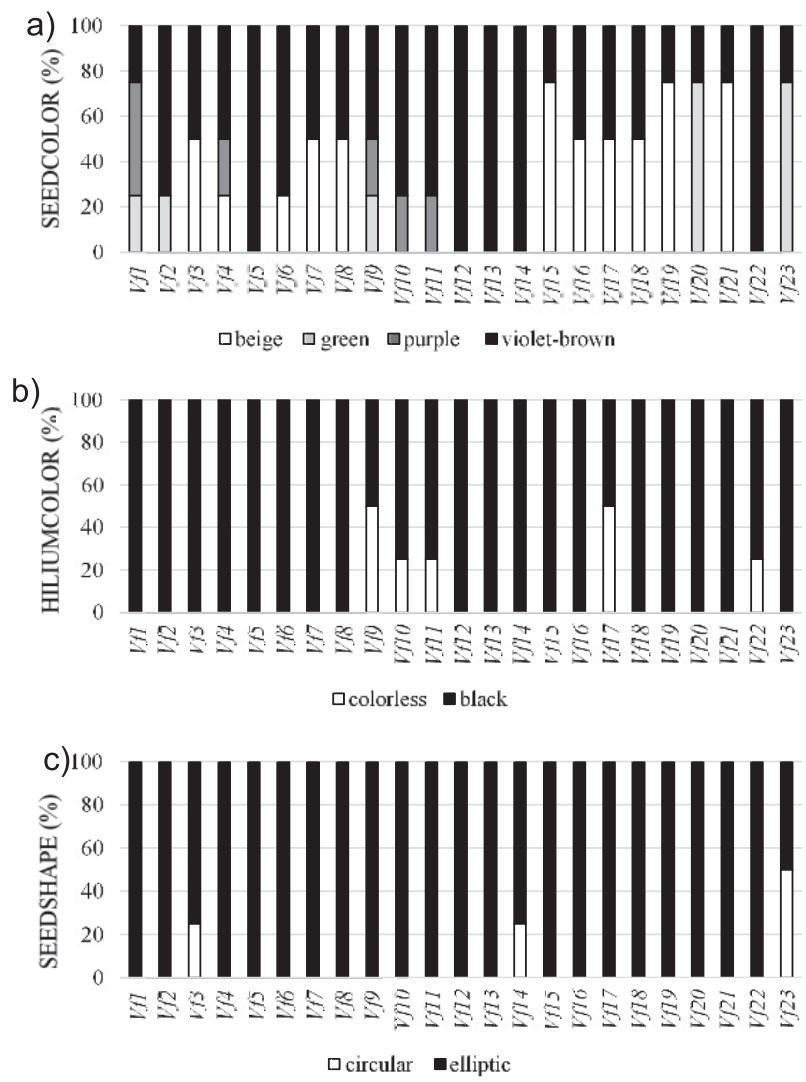

Fig. 2. Qualitative yield component traits of the studied Vicia faba var minor populations; a) Color of seed; b) Hilum color; c) Seed shape 
influence the content and composition of walls via the morphological composition, so that high temperatures stimulate rapid lignifications of supporting tissues. In addition, other feed quality traits related particularly to ruminant in vitro digestibility were evaluated. The digestibility of faba beans differs from one population to another; Vf3 recorded the lowest value in IVDMD (75.84 \%) and IVOMD (72.71\%), while Vf2 exhibited the highest values in IVDMD (96.52\%) and IVOMD (95.74\%). According to [51], proteins can form an insoluble complex with the presence of anti-nutritional factors, mainly tannins, and consequently, reducing its digestibility. In general, digestibility is influenced by several factors such as climatic conditions, harvesting, and storage conditions and the interactions between these factors [52]. Other sources of variation may also affect in vitro digestibility such as fineness of grinding, incubation time, proportion of rumen / saliva juice, and in some cases, the quality of rumen juice [53]. In our study, digestibility variation is correlated with fiber and CP content that varies between populations (Tables 6 and 7). Pearson's Correlation Matrix shows significant correlations between multiple pairs of variables (Table 7). There is therefore a linear relationship between the variables. In addition, IVDMD was positively correlated with ADF, IVOMD with ADF and IVDMD, then DM with NDF.

\section{Multivariate Analysis and Clustering of the Assessed Faba Bean Populations}

Breeding schemes are widely performed to valorize diverse genetic resources via the crucial steps of developing a Distinct, Homogenous, and Stable material serving as effective and suitable varieties regarding several selection criteria. In this context, several studies defined various traits providing a valuable representation of the existing diversity related to phenotypic classification as it is one of the crucial steps toward the germplasm clustering [54, 55]. For this, an appropriate selection of the superior genetic material needed for the breeding program which requires a good understanding of the genetic pool structure, the identification of more relevant variables, the detection of the relationships among traits and genotypes, as well as the identification of possible groups [56].

The cluster analysis for agro-morphological qualitative traits classified the populations into two groups (Fig. 3b). However, the PCA analysis from the same traits obtained by principal components showed that populations did not form distinct groups, with a wide dispersion among the populations (Fig. 3a). The first and second components represented $25.48 \%$ and $17.2 \%$ of the total variation observed among populations, respectively. A total of 8 duplicates were found in the cluster analysis (Fig. 3b), including the following populations: Vf12-Vf4, Vf18-Vf7, Vf23-Vf14, Vf20-Vf19, Vf8-Vf5, Vf15-Vf6, Vf22-Vf11 and Vf17Vfl.

The first group G1 was represented by the populations: Vf12, Vf4, Vf10, Vf18, Vf7, Vf2, Vf23, Vf14, $V f 3, V f 20, V f 19, V f 21$, and $V f 13$. These populations are more efficient and represent a better precocity (earliness regarding the three phenological stages studied). We noted here that among the materials of this cluster, $V f 2$ was distinguished by the highest digestibility and

b) Hierarchical cluster analysis ( complete linkage)

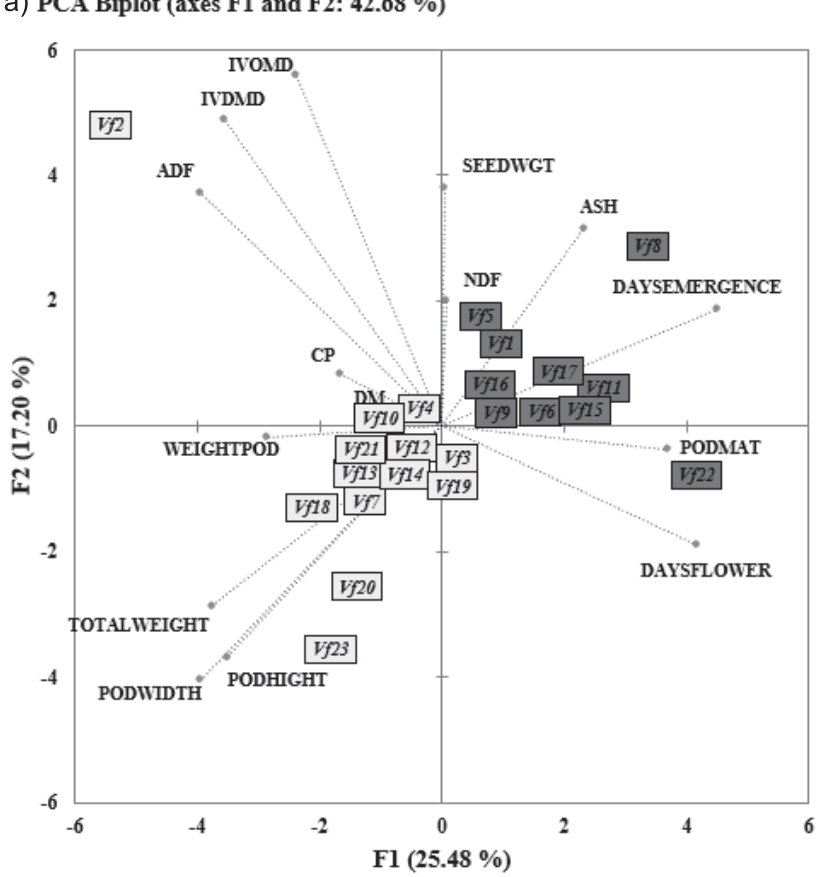

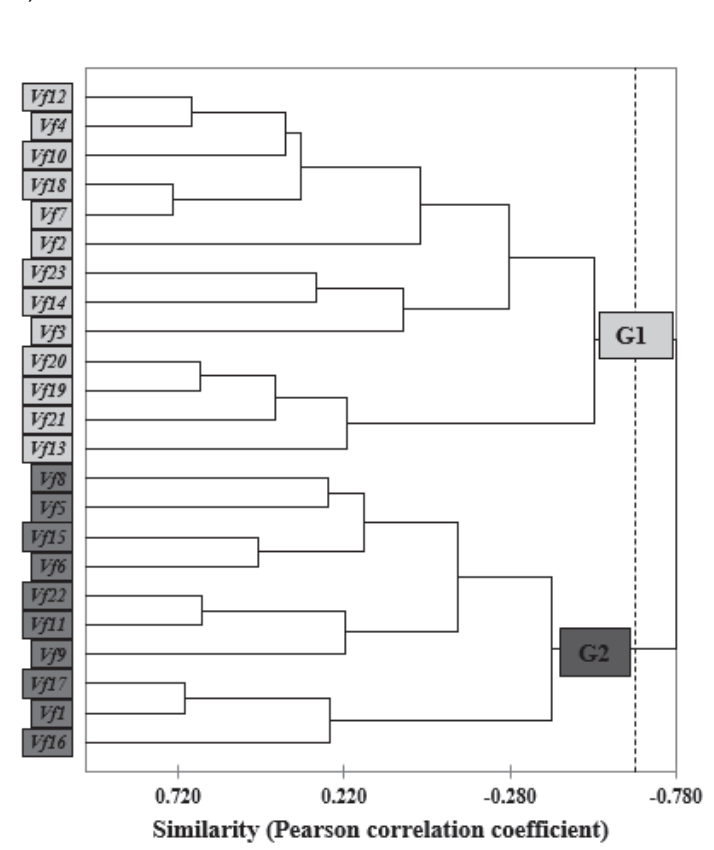

Fig. 3. Multivariate classification of the studied Vicia faba var minor populations based on the most discriminative traits; a) PCA Biplot b) Hierarchical cluster analysis. 
ADF content, while $V f 20$ and $V f 23$ exhibited the highest scores regarding pod dimensions and total yield.

The second group G2 including the following populations: Vf16, Vf1, Vf17, Vf9, Vf11, Vf22, Vf6, Vf15, $V f 5$, and $V f 8$ which are less performant than those of G1 except $V f 8$ which had the highest mineral composition (ash content).

This could help in genotype selection on the basis of PCA and hierarchical cluster analysis for phenolmorphological characterizations, yielding performances, and nutritional quality. The results also suggest the importance of these traits in the development of high yielding varieties.

Similar studies reporting these approaches were undertaken by [56].

The PCA analysis was widely applied as a key-approach to study the genetic structure in collections of genetic resources defining many crops $[56,57]$. In our study, we used this approach to identify the traits that were the main source of the variability based on morphological parameters (Fig. S1a, Table S2-A), yield components traits (Fig. S1b, Table $\mathrm{S} 2-\mathrm{B}$ ), and those related to nutritional quality (Fig. S1c, Table S2-C).

Regarding the pheno-morphological traits, the two PCs, F1 and F2, together account for $60.33 \%$ of the variability among the populations studied (Fig. S1a). We noted that the most discriminating traits were: the pod width, pod height and lifting period, which contributed respectively with $16.43 \%, 13.52 \%$ and $13.14 \%$ of the total variance over $\mathrm{F} 1$ axis versus flowering period and pod maturity period which defined the F2 axis with $40.69 \%$ and $33.71 \%$ of variances (Table S2-A).

On the other hand, the first two PCs, F1 and F2, performed on the basis of yield compound traits explained $86.93 \%$ of the variability (Fig. S1b) and revealed that pod weight and total weight were the main traits responsible for $22.08 \%$ and $21.57 \%$ of the variability described by the F1 axis while seed weight was the most representative trait on the F2 axis with $40.07 \%$ of the variability (Table S2b).

Except ADL, all the traits related to nutritional quality contributed to $52.86 \%$ of the variability on both F1 and F2 axes (Fig. S1c, Table S2-C).

In order to define the most important traits for faba bean breeders, [58] and [23] reported in their studies that there is a compromise between the precocity of flowering and the high number of pods per node and seeds per pod as yield components.

Based on the main traits chosen from each of the previous parts, a global PCA was carried out in order to classify our faba bean populations according to the gathered breeding criteria. This approach was considered to serve as a tool to select performant populations candidate to pursue the current breeding scheme. The analysis of the obtained PCs revealed $42.68 \%$ of the total variability. Our findings showed a narrower variability among Vicia faba var minor populations than those of [23] who found that both PCs accounted for $74.5 \%$ of the total variability among $V$. faba major and minor genotypes. This portion of the variation resulted mainly from the variation in the number of seeds per pod, number of pods per node, generative period, protein percentage, hundred seed weight, vegetative period, plant height and flowering period.

\section{Conclusion}

The knowledge of genetic diversity plays an important role in breeding strategies. Therefore, it is imperative to evaluate the variability of the local germplasm used in genetic improvement and breeding of high-yielding varieties that adapt to the agro-climatic drought conditions and small-scale farming systems.

Twenty-three faba bean populations of arid regions of Tunisia are used in this study. This active germplasm was collected from the agro-ecosystem of arid oasis. Future selections may potentially contribute to the wider use of traditional grain legume crops in agricultural systems throughout the arid regions of the Tunisian oasis. However, the level of genetic diversity of those populations that can be used in breeding programs has not yet been quantified.

This study was carried out to determine the extent of genetic diversity among Vicia faba var minor populations. They were studied in the experimental field of the arid regions institute, based on the assessment of their agro-morphological, chemical composition and in vitro digestibility differences.

The Obtained results revealed differences between all populations for all agro-morphological traits (qualitative and quantitative ones) as shown by multivariate analyses. The parameters have different correlations between them, some are correlated positively, others negatively. Thus, the cluster analysis distinguishes the differences between populations: It showed two groups with a total of 8 duplicates.

The populations Vf12, Vf4, Vf10, Vf18, Vf7, Vf2, $V f 23, V f 14, V f 3, V f 20, V f 19, V f 21$, and $V f 13$ are more performant and represent a better precocity, having the highest digestibility, ADF content and high total yielding.

Overall, we can assume that Faba bean could be one of the most important livestock fodder crops in Tunisian arid regions, improving the livelihood of smallholder farmers. The present study confirmed the existence of a wide phenotypic variation in this arid germplasm in many traits assessed. This genetic diversity is very useful for increasing the opportunities for genetic improvement of the yield potential in the faba bean crop through the development of synthetic variety in openpollinated conditions to increase genetic gains.

In fact, this agro-morphological characterization, chemical composition and in vitro digestibility of Tunisian arid faba bean is a preliminary study which 
can be reinforced by other more specific markers as biochemical and molecular markers.

There is also a need to start a breeding program to create new varieties for arid-oasis, which can tolerate diverse abiotic stresses and that guarantee a wide suitability to different cropping systems.

\section{Acknowledgments}

The authors are grateful to the Arid Land Institute direction for their support to carry out this research. Special thanks go to Miss Amina Gammoudi for her kind help with English revision.

\section{Conflict of Interest}

The authors declare no conflict of interest.

\section{References}

1. ETEMADI F., HASHEMI M., MANGAN F., XING B. Distribution of L -Dopa in different parts of faba Beans, in: Northeast Section of the American Society of Plant Biologists (NEASPB) Conference. The University of Rhode Island, RI 2. 2014.

2. ETEMADI F., HASHEMI M., MANGAN F., WEIS S. Faba beans; Growers guide in New England. http:// ag.umass.edu/sites/ag.umass.edu/files/research-reports/ faba_bean_guide_2.pdf, 2015.

3. ETEMADI F., BĀRKER A.V., HASHEMI M., ZANDVAKILI O.R., PARK Y. Nutrient accumulation in faba bean varieties. Commun Soil Sci Plant Anal, 49(16): 2064-2073, 2018.

4. ANGUS J.F., KIRKEGAARD J.A., HUNT J.R., RYAN M.H., OHLANDER L., PEOPLES M.B. Break crops and rotations for wheat. Crop Pasture Sci, 66, 523, 2015.

5. N'DAYEGAMIYE A., WHALEN J.K., TREMBLAY G., NYIRANEZA J., GRENIER M., DRAPEAU A., BIPFUBUSA M. The benefits of legume crops on corn and wheat: yield, nitrogen nutrition, and soil properties improvement. Agron J, 107, 1653, 2015.

6. ASCHI A., AUBERT M., RIAH-ANGLET W., NELIEU S., DUBOIS C., AK- PA-VINCESLAS M., TRINSOUTROTGATTIN I. Introduction of faba bean in crop rotation: impacts on soil chemical and biological characteristics. Appl Soil Ecol, 120, 219, 2017.

7. KHAN M.A., AMMAR M.H., MIGDADI H.M. Comparative nutritional profiles of various faba bean and chickpea genotypes. International Journal of Agriculture and Biology 17, 449, 2015.

8. WARSAME A.O., O'SULLIVAN D.M., TOSI P. Seed storage proteins of faba bean (Vicia faba L.): current status and prospects for genetic improvement. Journal of Agricultural and Food Chemistry, 66, 12617, 2018.

9. IVARSSON E., NEIL M. Variations in nutritional and antinutritional contents among faba bean cultivars and effects on growth performance of weaner pigs. Livestock Science, 212, 14, 2018.

10. ABDULLA J., ROSE S.P., MACKENZIE A.M., MIRZA W., PIRGOZLIEV V. Exogenous tannase improves feeding value of a diet containing field beans (Vicia faba) when fed to broilers. Brit Poult Sci., 57, 246, 2016.

11. WARSAME A.O., O'SULLIVAN D.M., TOSI P. Seed Storage Proteins of Faba Bean (Vicia faba L): Current Status and Prospects for Genetic Improvement J. Agric. Food Chem, 66, 12617, 2018.

12. GRESTA F., ALBERTINI E., RAGGi L., ABBATE V. A study of variability in the Sicilian faba bean landrace 'Larga di Leonforte'. Genet. Res. Crop. Evol., 57, 523, 2009.

13. MAGRINI M.B., ANTON M., CHOLEZ C., HELLOU C., DUC G., JEUFFROY M.H., MEYNARD J.M., PELZER E., VOISIN A.S., WALRAND S. Why are grainlegumes rarely present in cropping systems despite their environmental and nutritional benefits? Analyzing lock-in in the French agrifood system. Ecol Econ, 126, 152, 2016.

14. SAADANI O., HARZALLI S., IMEN J ., FATNASSI C., CHIBOUB M., MANNAI K., ZARRAD I., JEBARA M. Effect of Vicia faba L. var. minor and Sulla coronaria (L.) Medik associated with plant growth-promoting bacteria on lettuce cropping system and heavy metal phytoremediation under field conditions. Environmental Science and Pollution Research, doi. 10.1007/s11356-019-04302-2, 2019.

15. ABID G., MINGEOT D., UDUPA SM., MUHOVSKI Y., WATILLON B., SASSI K., M'HAMDI M., SOUISSI F., MANNAI K., BARHOUMI F., JEBARA M. Genetic relationship and diversity analysis of faba bean (Vicia faba L. var. minor) genetic resources using morphological and microsatellite molecular markers. Plant Mol. Biol. Rep., 33, 1755, 2015

16. ABID G., HESSINI K., AOUIDA M., AROUA I., BAUDOIN J.P., MUHOVSKI Y., MERGEAI G., SASSI K., MACHRAOUI M., SOUISSI F., JEBARA M. Agrophysiological and biochemical responses of faba bean (Vicia faba L. var. 'minor') genotypes to water deficit stress. Biotechnol. Agron. Soc. Environ., 21 (2), 146, 2017.

17. HADDOUDI I., MHADHBI H., GARGOURI M., BARHOUMI F., BEN ROMDHANE S., MRABET M. Occurrence of fungal diseases in faba bean (Vicia faba L.) under salt and drought stress. Eur J Plant Pathol, 159, 385, 2021.

18. ABBES Z., BOUALlEGUE A., TRABELSI I., TRABELSI N., TAAMALLI A., AMRI M., MHADHBI H., KHARRAT M. Investigation of some biochemical mechanisms involved in the resistance of faba bean (Vicia faba L.) varieties to Orobanche spp. Plant Protection Science, 56 (4), 317, 2020.

19. BODNER G., KRONBERGAB A., LEPSEC D.L, OLLEE M., VÅGENF I.M., RABANTEB L., FERNÁNDEZG J.A, NTATSIH G., BALLIUI A., REWALDJ B. Trait identification of faba bean ideotypes for Northern European Environments. EUR J AGRON. 96, 1, 2018.

20. ALMOUHANDES DRIDI B., LOUMEREM M., HOUIMLI S., JABBES N., TLAHIG S. Caractérisation phénomorphologique de quelques lignées de fève (Vicia faba L.) sélectionnées et adaptées aux conditions de culture dans les régions arides en Tunisie. Africa focus. 24, 71, 2011.

21. YAHIA Y., GUETAT A., ELFALLEH W., FERCHICHI A., Hédi YAHIA H., LOUMEREM M. Analysis of agromorphological diversity of southern Tunisia faba bean (Vicia faba L.) germplasm. African Journal of Biotechnology. 56, 11913, 2012.

22. TLAHIG S., BELLANI L., KARMOUS I., BARBIERI F., LOUMEREM M., MUCCIFORA S., Response to 
Salinity in Legume Species: An Insight on the Effects of Salt Stress during Seed Germination and Seedling Growth Chem. Biodiversity. 18, e2000917. https://doi.org/10.1002/ cbdv.202000917, 2021.

23. National Observatory of Agriculture (ONAGRI), Tunisian Ministry of Agriculture, 2016.

24. LOUMEREM M., MOUSSA M., BELLACHHEB C. The collection and study of the genetic diversity of species cultivated in hydraulic systems in arid Tunisian regions. Revue des Régions Arides - ISSN 0330-7956, Proceedings of International Seminar, Dryland Farming and Oasis Cropping, 22-25 / 11/2004, 2004.

25. Union internationale pour la Protection des Obtentions Végétales (UPOV). Guidelines for the Conduct of Tests for Distinctness, Homogeneity and Stability - Lucerne (Medicago sativa L. and Medicago varia Martyn.). Genève. 9, 1990.

26. Association of Official Analytic Chemists (AOAC). Official Methods of Analysis $15^{\text {th }}$ ed. (Arlington, USA), 1990.

27. VAN SOEST P.J., ROBERTSON J.B., LEWIS B.A. Methods for dietary fibre and non starch polysaccharides in relation to animal nutrition. J. Dairy Sci. 74, 3583, 1991.

28. TILLEY J.M.A., TERRY R.A. A two-stage technique for the in vitro digestion of forage crops Current Contents. J. Br. Grassl. Soc. 18, 104, 1963.

29. MEGAHED H., AMMAR S., ALGHAMDI H., MIGDADI M., MUHAMMAD A., KHAN H., EL-HARTY S., ALFAIFI A. Assessment of genetic diversity among faba bean genotypes using agro-morphological and molecular markers. Saudi J Biol Sci. 22, 340, 2015.

30. LABBA I.C.M., FRØKIÆR H., SANDBERG A.S. Nutritional and antinutritional composition of fava bean (Vicia faba L., var. minor) cultivars. Food Research International 140. https://oi.org/10.1016/j. foodres.2020.110038, 2021.

31. OMER S., UFUK K. Determination of Morphological and Phenological Properties of Faba Beans Grown in Eastern Mediterranean Region of Turkey Tarla Bitkileri Merkez Araştırma Enstitüsü Dergisi. 25 (2), 209, 2016.

32. MAALOUF F., AHMED S., SOMANAGOUDA P. Developing improved varieties of faba bean. Achieving sustainable cultivation of grain legumes: Improving cultivation of particular grain legumes. Cambridge, UK: Burleigh Dodds Science Publishing. 2, 253, 2018.

33. ETEMADI A.F., HASHEMI M.A., ALLEN V., BARKER A., ZANDVAKILI A.O.R., LIU B.X. Agronomy, Nutritional Value, and Medicinal Application of Faba Bean ( Vicia faba L.). Horticultural Plant Journal, 5 (4), 170, 2019.

34. HARKER K.N., O'DONOVAN J.T., SMITH E.G., JOHNSON E.N., PENG G., WIL-LENBORG C.J., GRENKOW L.A. Seed size and seeding rate effects on canola emergence, development, yield and seed weight. Can J Plant Sci, 95, 1, 2015

35. GEZAHEGN A.M., TESFAYE K., SHARMA J.J., BELEL M.D. Determination of optimum plant density for faba bean (Vicia faba L.) on vertisols at Haramaya, Eastern Ethiopia. Cogent Food Agric, 2, 1, 2016

36. PATEL J.B., BHATIYA V.J., BABARIYA C.A., SONDARVA J. Effect of seed size on seedling vigour, plant growth, seed yield and its parameters: a review. Res Environ Life Sci, 9, 859, 2016.

37. ULUKAN H., GULER M., KESKIN S. A Path Coefficient Analysis Some Yield and Yield Components in Faba Bean
(Vicia faba L.) Genotypes. Pakistan Joumal of Biological Sciences. 6 (23), 1951, 2003.

38. SHARIFI P. Genetic variation for seed yield and some of agro-morphological traits in faba bean (Vicia faba L.) genotypes. Acta agriculturae Slovenica. 105 (1), 73, 2015.

39. MOUHAMED K.M.M. The Relationship between Yield and Heritability in Ten Genotypes of Faba Bean (Vicia faba L.). Hereditary Genet, 8 (1), 197. 6p, 2019.

40. RENNA M., MONTESANO F., GONNELLA M., SIGNORE A., SANTAMARIA P. A case study of integrated project to preserve the biodiversity of vegetable crops in Puglia (Southern Italy). Agriculture, 8, 128,2018

41. OLLE M., WILLIAMS I.H., ROSA E. Selecting appropriate faba bean var. minor varieties for production under Northern European environmental conditions. Acta Agriculturae Scandinavica, Section B - Soil \& Plant Science, 96, 1651, 2019.

42. SHANG R., WU H., GUO R., LIU Q., PAN L., LI J., CHEN C. The diversity of four anti-nutritional factors in common bean. Horticultural Plant Journal, 2, 97, 2016.

43. ETEMADI F., HASHEMI M., ZANDVAKILI O., MANGAN F. Phenology yield and growth pattern of faba bean varieties. Int J Plant Prod, 1, 2018.

44. LIZARAZO C.I., LAMPI A.M., LIU J., TUULA S.S., PIIRONENB V., STODDARDA L.F. Nutritive quality and protein production from grain legumes in a boreal climate. J Sci Food Agric. 95, 2053, 2014.

45. TAO A., AFSHAR R. K., HUANG J., MOHAMMED Y. A., ESPE M., CHEN C. Variation in Yield, Starch, and Protein of Dry Pea Grown across Montana. Agronomy Journal, 4, 1491, 2017.

46. ROBINSON G.H.J., BALK J., DOMONEY C. Improving pulse crops as a source of protein, starch and micronutrients. Nutrition Bulletin published by John Wiley \& Sons Ltd on behalf of British Nutrition Foundation Nutrition Bulletin, 44, 202, 2019.

47. STRYDHORST M.S., KING J.R., LOPETINSKY K.J., HARKER N.K. Forage Potential of Intercropping Barley with Faba Bean, Lupin, or Field Pea. AGRON J. 100, 182, 2008.

48. ADAPA P., TABIL L., SCHOENAU G. Compaction characteristics of barley, canola, oat and wheat straw. Biosyst Eng. 104, 335, 2009.

49. MELAKU S., DAWIT A. Effect of supplementing ureatreated barley straw with lucerne or vetch hays on feed intake, digestibility and growth of Arsi Bale Sheep. Trop Anim Health Prod. 41, 579, 2008.

50. JEZIERNY D., MOSENTHIN R., SAUER N., SCHWADORF K., ROSENFELDER-KUON P. Methodological impact of starch determination on starch content and ileal digestibility of starch in grain legumes for growing pigs. J. Anim. Sci. Biotechnol. 8, 4, 2017.

51. CRÉPON K., MARGET P., PEYRONET C., CARROUÉE B., ARESE P., DUC G. Nutritional value of faba bean (Vicia faba L.) seeds for feed and food. Field Crop Res. 115, 329, 2010.

52. PICON-COCHARD C., BLOOR J., ZWICKE M., DURU M. Impacts du changement climatique sur les prairies permanentes. Fourrages, 214, 127, 2013.

53. CHENOST M., GRENET E., DEMARQUILLY C., JARRIGE R. The use of the nylon bag technique for the study of forage digestion in the rumen and for predicting feed value. Proceedings of the XIth International Grassl and Congress. 697, 1970. 
54. SMITH S.E., DOSS A.L., WARBURTON M. Morphological and agronomical variation in North African and Arabian alfalfas. Crop Sci., 31 (5), 1159, 1991.

55. GHAFOOR A., AFZAL M., ANWAR R. Diversity in food legumes for sustainable utilization of plant genetic resources. In: Sustainable utilization of plant genetic resources for agricultural production (Eds.: Anwar, R. Takahashi, J. Bhatti, M.S. Masood, S.) PARC/IPGRI/ JICA, Islamabad, Pakistan: 238, 2003.

56. TLAHIG S., KARMOUS I., GORAI M., JAOUADI T., LOUMEREM M. Effect of cutting time on the performance of alfalfa (Medicago sativa L.) genotypes cropped in arid environment. Pol. J. Environ. Stud. 30 (2), 1817, 2021.

57. MARTINEZ-CALVO J., GISBERT A.D., ALAMAR M.C., HERNANDORENA R., ROMERO C., LLACER G., BADENES M.L. Study of a germplasm collection of loquat (Eriobotrya japonica Lindl.) by multivariate analysis. Genet. Res. Crop. Evol. 55 (5), 695, 2008.

58. DUC G. Faba bean (Vicia faba L.). Field Crops Res. 53, 99, 1997.

\section{Supplementary Material}

Table S1. Composition of the Artificial saliva solution used for in vitro digestibility analysis.

\begin{tabular}{|c|c|c|}
\hline Solutions & Buffers & Quantity (g/l) \\
\hline \multirow{4}{*}{ Solution (a) } & $\mathrm{NaCl}$ & 2.35 \\
\hline & $\mathrm{K} \mathrm{Cl}$ & 2.25 \\
\hline & $\mathrm{MgCl}_{2} 6 \mathrm{H}_{2} \mathrm{O}$ & 0.5013 \\
\hline & $\mathrm{CaCl}_{2}$ & 0.275 \\
\hline Solution (b) & $\mathrm{NaHCO} 3$ & 46.2 \\
\hline Solution (c) & $\mathrm{Na}_{2} \mathrm{HPO}_{4}$ & 28.2 \\
\hline \multirow{3}{*}{ Solution (d) } & $\mathrm{FeSO}_{4} 7 \mathrm{H}_{2} \mathrm{O}$ & 7.5 \\
\hline & $\mathrm{CuSO}_{4} 5 \mathrm{H}_{2} \mathrm{O}$ & 0.2 \\
\hline & $\mathrm{ZnSO}_{4} 2 \mathrm{H}_{2} \mathrm{O}$ & 0.01 \\
\hline Solution (e) & Blue methylene & 0.1 \\
\hline \multirow{3}{*}{ Solution (f) } & Cysteine $\mathrm{HCl}$ & 0.625 \\
\hline & Distilled $\mathrm{H}_{2} \mathrm{O}$ & $95 \mathrm{ml}$ \\
\hline & $\mathrm{NaOH}(1 \mathrm{~N})$ & $4 \mathrm{ml}$ \\
\hline
\end{tabular}

Table S2. Contribution of the assessed traits on the variability based on the PCA.

\begin{tabular}{|c|c|c|c|c|c|c|c|c|}
\hline \multicolumn{2}{|c|}{ A. pheno-morphological traits } & \multicolumn{3}{c|}{ B. yield compounds traits } & \multicolumn{3}{c|}{ C. Nutritional quality traits } \\
\hline & F1 $(\%)$ & F2 $(\%)$ & & F1 (\%) & F2 (\%) & & F1 (\%) & F2 (\%) \\
\hline FLWPERINF & 8.06 & 1.77 & PODPLANT & 15.13 & 16.08 & NDF & 12.34 & $\mathbf{2 9 . 8 4}$ \\
\hline LENGTHLEALET & 8.31 & 5.22 & TOTALWEIGHT & $\mathbf{2 1 . 5 7}$ & 9.79 & ADF & $\mathbf{2 7 . 4 4}$ & 0.01 \\
\hline PLANTHGT & 8.32 & 7.43 & WEIGHTPOD & 22.08 & 13.00 & ADL & 0.55 & 0.01 \\
\hline STEMNBR & 12.73 & 1.23 & SEEDSPOD & 18.66 & 6.66 & IVDMD & $\mathbf{2 5 . 2 1}$ & 12.91 \\
\hline PODHIGHT & $\mathbf{1 3 . 5 2}$ & 6.64 & WGHTSEEDPOD & 21.40 & 14.39 & IVOMD & $\mathbf{2 6 . 9 6}$ & 8.18 \\
\hline PODWIDTH & $\mathbf{1 6 . 4 3}$ & 0.50 & SEEDWGT & 1.15 & $\mathbf{4 0 . 0 7}$ & DM & 6.67 & $\mathbf{2 1 . 8 0}$ \\
\hline NODNBR & 9.95 & 0.91 & & & & ASH & 0.62 & $\mathbf{1 9 . 0 0}$ \\
\hline DAYSEMERGENCE & $\mathbf{1 3 . 1 4}$ & 1.90 & & $\mathbf{C P}$ & 0.21 & $\mathbf{8 . 2 7}$ & & \\
\hline DAYSFLOWER & 4.18 & $\mathbf{4 0 . 6 9}$ & & & & & \\
\hline PODMAT & 5.37 & $\mathbf{3 3 . 7 1}$ & & & & & \\
\hline
\end{tabular}


a) Pheno-morphological traits (axes F1 and F2: 60,33\%)

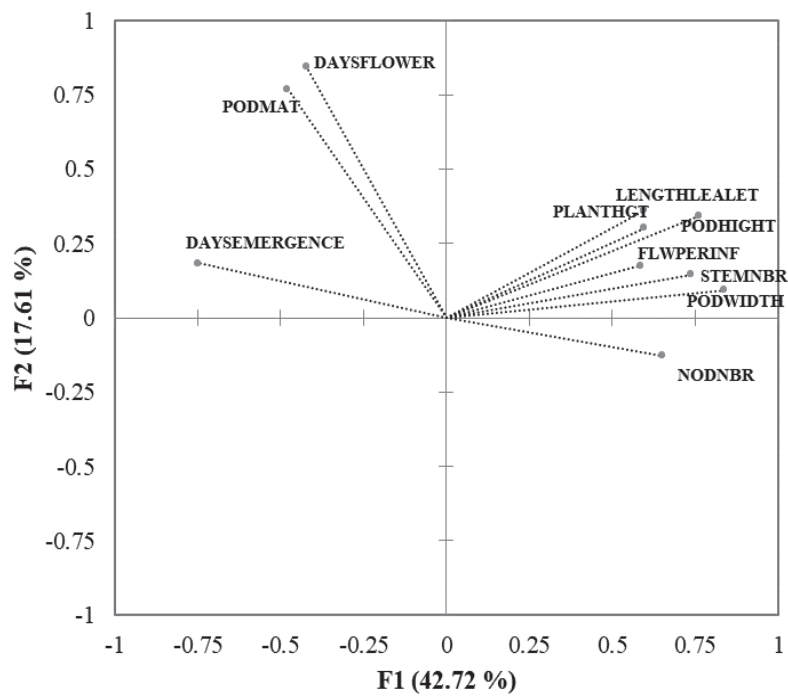

b) Yield components (axes F1 and F2: $86.93 \%$ )

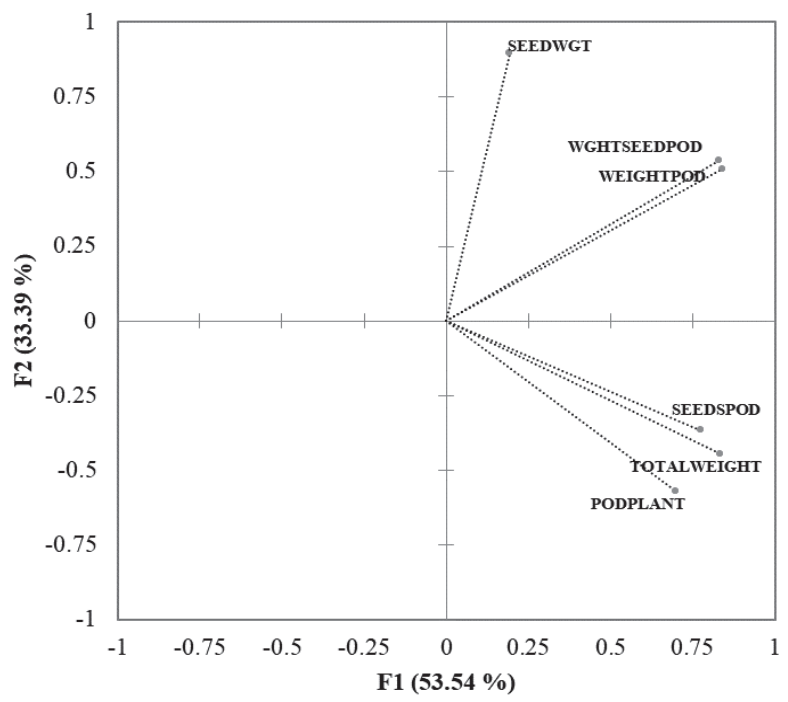

c) Nutritional quality traits (axes F1 and F2: $52.86 \%$ )

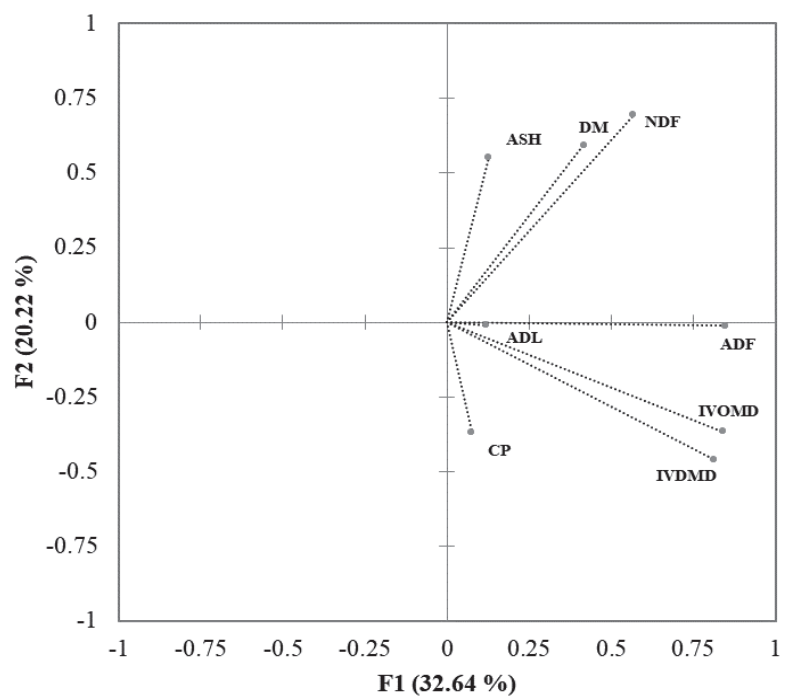

Fig. S1. Principal Component Analysis (PCA) related to phenomorphological, a) yield components, b) and nutritional quality, c) traits. 